\title{
Applications and challenges of next-generation sequencing in Brassica species
}

\author{
Lijuan Wei · Meili Xiao · Alice Hayward · Donghui Fu
}

Received: 7 September 2013 / Accepted: 12 September 2013 / Published online: 24 September 2013

(C) Springer-Verlag Berlin Heidelberg 2013

\begin{abstract}
Next-generation sequencing (NGS) produces numerous (often millions) short DNA sequence reads, typically varying between 25 and $400 \mathrm{bp}$ in length, at a relatively low cost and in a short time. This revolutionary technology is being increasingly applied in whole-genome, transcriptome, epigenome and small RNA sequencing, molecular marker and gene discovery, comparative and evolutionary genomics, and association studies. The Brassica genus comprises some of the most agro-economically important crops, providing abundant vegetables, condiments, fodder, oil and medicinal products. Many Brassica species have undergone the process of polyploidization, which makes their genomes exceptionally complex and can create difficulties in genomics research. NGS injects new vigor into Brassica research, yet also faces specific challenges in the analysis of complex crop genomes and traits. In this article, we review the advantages and limitations of different NGS technologies and their applications and challenges, using Brassica as an advanced model system for agronomically important, polyploid crops. Specifically, we focus on the use of NGS for genome resequencing,
\end{abstract}

L. Wei · D. Fu ( $₫)$

Key Laboratory of Crop Physiology, Ecology and Genetic Breeding, Ministry of Education, Agronomy College, Jiangxi Agricultural University, Nanchang 330045, China e-mail: fudhui@163.com

\section{Wei $\cdot$ M. Xiao}

Chongqing Engineering Research Center for Rapeseed, College of Agronomy and Biotechnology, Southwest University, Chongqing 400716, China

\section{A. Hayward}

Centre for Integrative Legume Research, School of Agriculture and Food Sciences, The University of Queensland, St Lucia 4072, Australia transcriptome sequencing, development of single-nucleotide polymorphism markers, and identification of novel microRNAs and their targets. We present trends and advances in NGS technology in relation to Brassica crop improvement, with wide application for sophisticated genomics research into agronomically important polyploid crops.

Keywords Polyploidy $\cdot$ Next-generation sequencing . Brassica $\cdot$ Single-nucleotide polymorphism (SNP) · Transcriptome $\cdot$ Genome sequencing

\section{Introduction}

Next-generation sequencing (NGS) platforms rapidly sequence entire genomes in the form of millions of short DNA fragments in a cost-effective and high-throughput manner. NGS has been widely applied in plant and animal genomic de novo sequencing (Al-Dous et al. 2011; Li et al. 2010; Xu et al. 2011), resequencing (Ashelford et al. 2011; Lam et al. 2010; Xia et al. 2009), methylation sequencing (Cokus et al. 2008; Lister et al. 2008, 2009; Baranzini et al. 2010; Dowen et al. 2012) and transcriptome and small RNA sequencing (Buggs et al. 2012; Strickler et al. 2012) for a plethora of functional and comparative genomics analyses. In complex polyploid species, including many of the world's most agronomically important crops, genomics may be hampered by poor discrimination between homeologous fragments during sequence assembly. However, advances in NGS technologies and the associated computational algorithms required to analyze massive, complex data sets present huge potential for complex genome analysis and development of improved genomics-based breeding strategies (Aversano et al. 2012). 
The Brassica genus contains the most diverse collection of agronomically important plant species and is a relative of the model plant Arabidopsis thaliana, from which it diverged $\sim 20$ Mya. The six most agro-economically important Brassica species include the three diploid species, Brassica rapa (AA, $2 \mathrm{n}=20)$, Brassica oleracea $(\mathrm{CC}, 2 \mathrm{n}=18)$ and Brassica nigra $(\mathrm{BB}, 2 \mathrm{n}=16)$, and the three allotetraploid species, Brassica juncea (AABB, $2 \mathrm{n}=34$ ), Brassica napus (AACC, $2 \mathrm{n}=38$ ) and Brassica carinata $(\mathrm{BBCC}, 2 \mathrm{n}=36$ ), which were formed through the hybridization of their diploid genome counterparts (U N 1935). World-wide, approximately $12 \%$ of edible vegetable oil is provided by $B$. napus, $B$. rapa, B. juncea and B. carinata, and the global production of Brassica crops has doubled in the last 15 years. Given that many Brassica crop species are polyploids, the wellstudied relationships between the diploid progenitor species and their corresponding tetraploids, combined with relatively small genomes, make Brassica species highly useful models for investigating the genetic and evolutionary mechanisms of polyploidisation (Edwards et al. 2013).

The genome of diploid and tetraploid Brassica species (1.2 Gbp) are 3-5 times and 10 times greater than that of A. thaliana, respectively (Arumuganathan and Earle 1991). Genome duplication combined with gene loss and insertion (Town et al. 2006; Mun et al. 2009), chromosomal rearrangements, and rapid divergence of repeat sequences (Koo et al. 2011) are frequent effects of polyploidization, which has complicated Brassica genome structure. As such, the complex structure of polyploid Brassica genomes has made genome sequencing and assembly challenging. Fortunately, with advances in technologies and software, dissecting polyploid genomes has become possible. The current trend towards the application of NGS platforms in numerous plant and animal species will profoundly affect genomic research, improving our understanding of molecular and evolutionary mechanisms underlying variations in a species' phenotype, development and responses to environmental stressors.

This article will compare various NGS platforms and discuss advances and trends in their use with emphasis on their application and challenges in Brassica research and breeding. In so doing, this review will highlight the impacts of NGS in Brassica research as a model system for understanding the molecular basis of polyploidy in important crop species.

\section{Characteristics and comparative analysis of various generations of sequencing technologies}

First-generation sequencing

First-generation sequencing is based on the chain termination method invented by Frederick Sanger (Sanger et al.
1977). Today, this method has been automated and commercialized using sequencing machines available through companies including Applied Biosystems (USA) and Beckman Coulter (USA). Sanger sequencing has dominated the DNA sequencing industry for almost three decades, providing sequence reads between 450 and 1,000 bp in length at high accuracies $(99.999 \%)$. The human genome (International Human Genome Consortium 2004) and the genome of model plant species, A. thaliana, followed by two rice varieties: Oryza sativa L. ssp. japonica and Oryza sativa L. ssp. indica have been completed (Goff et al. 2002; Yu et al. 2002). More recently, the genomes of Brachypodium distachyon (The International Brachypodium Initiative 2010), Populus trichocarpa (poplar; Tuskan et al. 2006), Prunus persica (peach; http://www.rosaceae.org/peach/genome), Sorghum bicolor (sorghum; Paterson et al. 2009), and Glycine $\max$ (soybean; Schmutz et al. 2010) were sequenced (Table 1).

For Brassica species, the first physical map of Brassica A genome of B. rapa was constructed based on 67,468 BAC clones, spanning $717 \mathrm{Mb}$ in physical length, fingerprinted by Sanger sequencing (Mun et al. 2008). The $B$. rapa A3 chromosome (31.9 Mb) was also obtained using traditional Sanger sequencing methods, incorporating 348 overlapping BAC clones (Mun et al. 2010).

Although first-generation sequencing enabled initial whole-genome sequencing efforts, significant limitations in Sanger sequencing technology exist. Firstly, conventional Sanger sequencing is still relatively expensive, currently 0.5 per kilobase, and while this cost has declined over the last few years (Snowdon and Luy 2012), it would cost $\$ 5,000,000$ to sequence a $1 \mathrm{~Gb}$ genome to $10 \times$ coverage. Secondly, Sanger technology is difficult to improve upon since it depends on capillary electrophoresis separation of fluorescently labeled fragments (Varshney et al. 2009). Thirdly, the throughput ( $70 \mathrm{Kbp}$ of data per run) is exceedingly low, making it time-intensive to obtain genetic information, particularly for large numbers of samples in parallel. Thus, Sanger sequencing technology continues to be beneficial and widely applied for low throughput projects, for example, sequence validation of PCR products and BAC end sequences, but is not efficacious for mainstream genome and transcriptome sequencing, particularly of complex genomes. Such larger-scale studies require higher throughput technologies. As such, sequencing technologies able to multiplex numerous samples in parallel to obtain vast quantities of genetic information were more recently developed, collectively called NGS.

\section{Next-generation sequencing}

With advancements in molecular research and the increasing demand for large quantities of nucleotide sequences 
Table 1 Plant species that have been sequenced using sequencing technologies

\begin{tabular}{|c|c|c|c|c|}
\hline Species & Sequencing accession & Sequencing methods & Genome size & Reference \\
\hline Arabidopsis & Columbia & Sanger sequencing & $125 \mathrm{Mb}$ & Kaul et al. (2000) \\
\hline Rice & $\begin{array}{l}\text { Oryza sativa L. ssp. Indica } \\
\text { "93-11"/japonica "Nipponbare" }\end{array}$ & Sanger sequencing $(4.2 \times)$ & $466 \mathrm{Mb}$ & $\begin{array}{l}\text { Goff et al. (2002), Yu et al. } \\
\text { (2002) }\end{array}$ \\
\hline B. distachyon & Diploid lines "Bd21" & Sanger sequencing $(9.4 \times)$ & $272 \mathrm{Mb}$ & $\begin{array}{l}\text { The International Brachypodium } \\
\text { Initiative (2010) }\end{array}$ \\
\hline P. trichocarpa & $\begin{array}{l}\text { A single female genotype "Nisqually } \\
1, "\end{array}$ & Sanger sequencing $(7.5 \times)$ & $370 \mathrm{Mb}$ & Tuskan et al. (2006) \\
\hline Papaya & Tansgenic fruit tree "SunUp" & Sanger sequencing $(3 \times)$ & $372 \mathrm{Mb}$ & Ming et al. (2008) \\
\hline Peach & Doubled haploid cultivar 'Lovell' & Sanger sequencing $(7.7 \times)$ & $227 \mathrm{Mb}$ & $\begin{array}{l}\text { International Peach Genome } \\
\text { Initiative (2010) }\end{array}$ \\
\hline Sorghum & Homozygous genotype "BT $\times 623$ " & Sanger sequencing $(8.5 \times)$ & $\sim 730 \mathrm{Mb}$ & Paterson et al. (2009) \\
\hline Soybean & Cultivar "Williams 82" & Sanger sequencing & $1.1 \mathrm{Gbp}$ & Schmutz et al. (2010) \\
\hline Cucumber & Inbred line 'Chinese long' 9930 & $\begin{array}{l}\text { Sanger }(3.9 \times) \text { and Illumina GA } \\
(68.3 \times)\end{array}$ & $243.5 \mathrm{Mb}$ & Huang et al. (2009) \\
\hline Watermelon & Chinese elite inbred line 97103 & Illumina GAII $(108.6 \times)$ & $353.5 \mathrm{Mb}$ & Guo et al. (2012a) \\
\hline Barley & Cultivar "Morex" & Illumina GAII and Roche 454 & $4.98 \mathrm{~Gb}$ & Mayer et al. (2012) \\
\hline Sweet orange & Dihaploid & Illumina GAII & $367 \mathrm{Mb}$ & Xu et al. (2012a) \\
\hline Potato & $\begin{array}{l}\text { Double monoploid "Phureja DM1-3 } \\
516 \text { R44" }\end{array}$ & $\begin{array}{l}\text { Illumina GA, Roche } 454 \text { and } \\
\text { Sanger platforms }\end{array}$ & $844 \mathrm{Mb}$ & Xu et al. (2011) \\
\hline Cotton & G. raimondii & Illumina HiSeq2000 (103.6× $)$ & $775.2 \mathrm{Mb}$ & Wang et al. (2012b) \\
\hline Bread wheat & Chinese Spring "CS42" & 454 pyrosequencing $(5 \times)$ & $17 \mathrm{~Gb}$ & Brenchley et al. (2012) \\
\hline
\end{tabular}

came the development of fast, high-throughput and costeffective NGS technology. NGS technology has been widely applied in recent years and includes a few major products with different chemistries, including 454 sequencing (Roche Applied Science), Solexa (now Illumina) technology (Illumina inc.), SOLiD (Applied Biosystems), and Polonator G. 007 (http://www.polonator.org/) (Table 2).

The first NGS sequencing instrument on the market was the GS20, developed by Roche Applied Science (USA). Recently, the Roche 454 GS FLX+ system was commercialized, yielding up to $700 \mathrm{Mb}$ of sequence per run comprising $1,000 \mathrm{bp}$ sequence reads with an accuracy of $99.997 \%$. This system includes the software required for assembly and mapping of these sequences reads into contiguous sequence, as well as amplicon variant analysis (Klein et al. 2011; Mundry et al. 2012). The Roche 454 GS has proven efficacy in Brassica genome sequencing (Wang et al. 2011b), and improves the accuracy of mapping homeologous fragments because the relatively long length of sequence reads increases specificity. Nonetheless, the Roche 454 GS remains costly as compared to other NGS technologies.

Solexa sequencing, now provided by Illumina (including the HiSeq and MiSeq instruments), can generate up to $200 \mathrm{bp}$ per read and up to $600 \mathrm{Gbp}$ of data per run. Error rates for this system are approximately $0.1 \%$, primarily resulting from substitution errors, rather than insertions or deletions in the sequencing and detection process
(Minoche et al. 2011). Illumina sequencing is cost-effective and highly suited to the sequencing of short Brassica target sequences such as transcriptome sequences and small RNAs. However, its application as a sole NGS technology for whole-genome sequencing is limited by its relatively short-read lengths.

The ABI SOLiD platform (version 4) clonally amplifies template fragments with emulsion PCR, using DNA ligase rather than a polymerase and fluorescently labeled oligonucleotides. Another feature is the use of two-base encoding, which identifies each base twice to reduce the error rate. However, the speed of sequencing is relatively slow, and the read length is only around 85 bp (Edwards and Batley 2010). The Polonator G 007 is similar to the SOLiD system, and the technology platform is open for manipulation and improvement by the user. However, the current read length is less than $30 \mathrm{bp}$ (Morey et al. 2013) and while vast quantities of data can be obtained from clonal amplification sequencing, read length is much shorter than that of other NGS platforms, reducing the applicability to sequence assembly and subsequent analysis in polyploid species including the amphidiploid Brassicas.

The third-generation sequencing

Single-molecule sequencing technology directly analyses light signals generated by cellular nucleic acids without a requirement for clonal amplification or ligation in template 


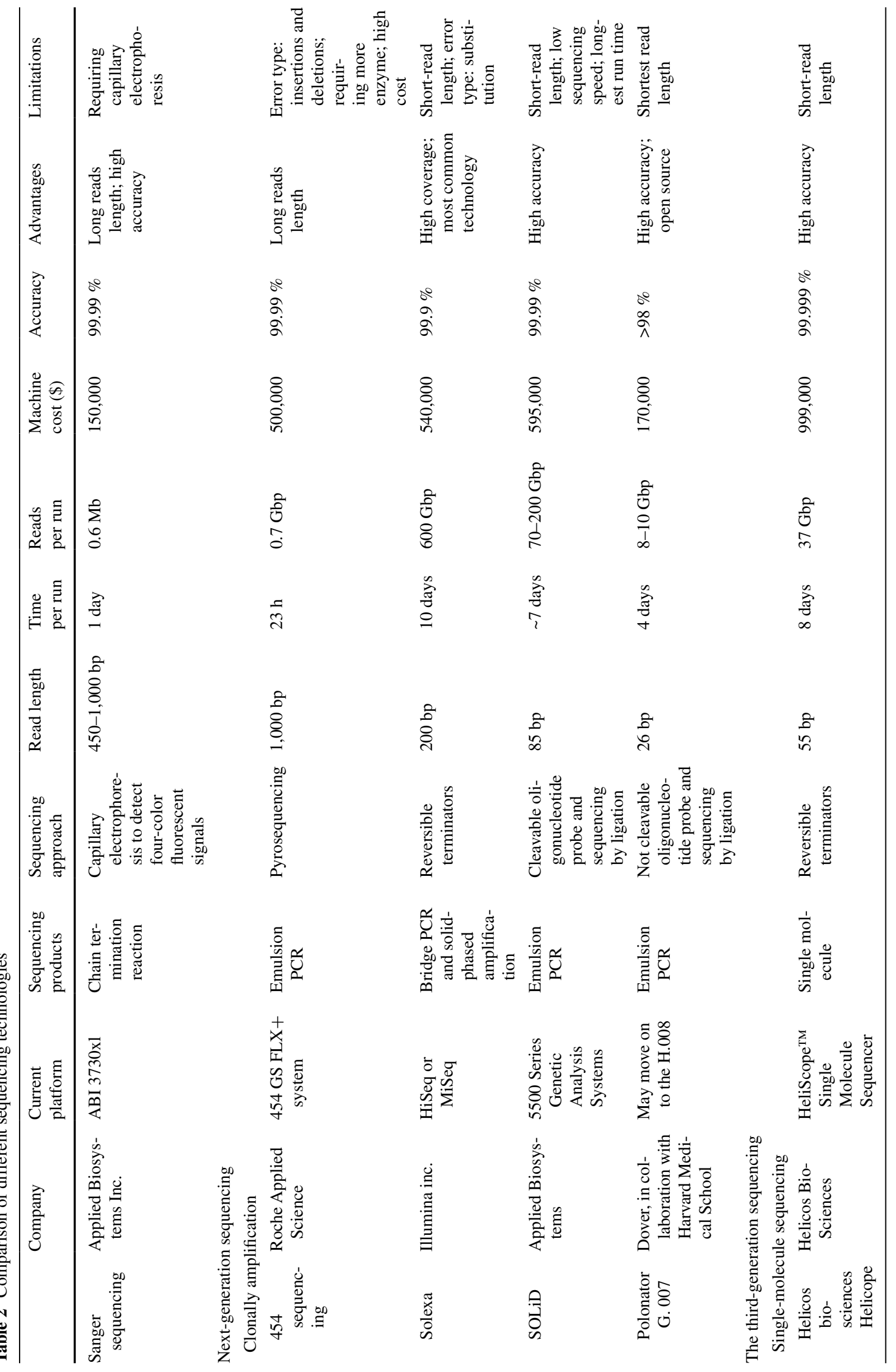




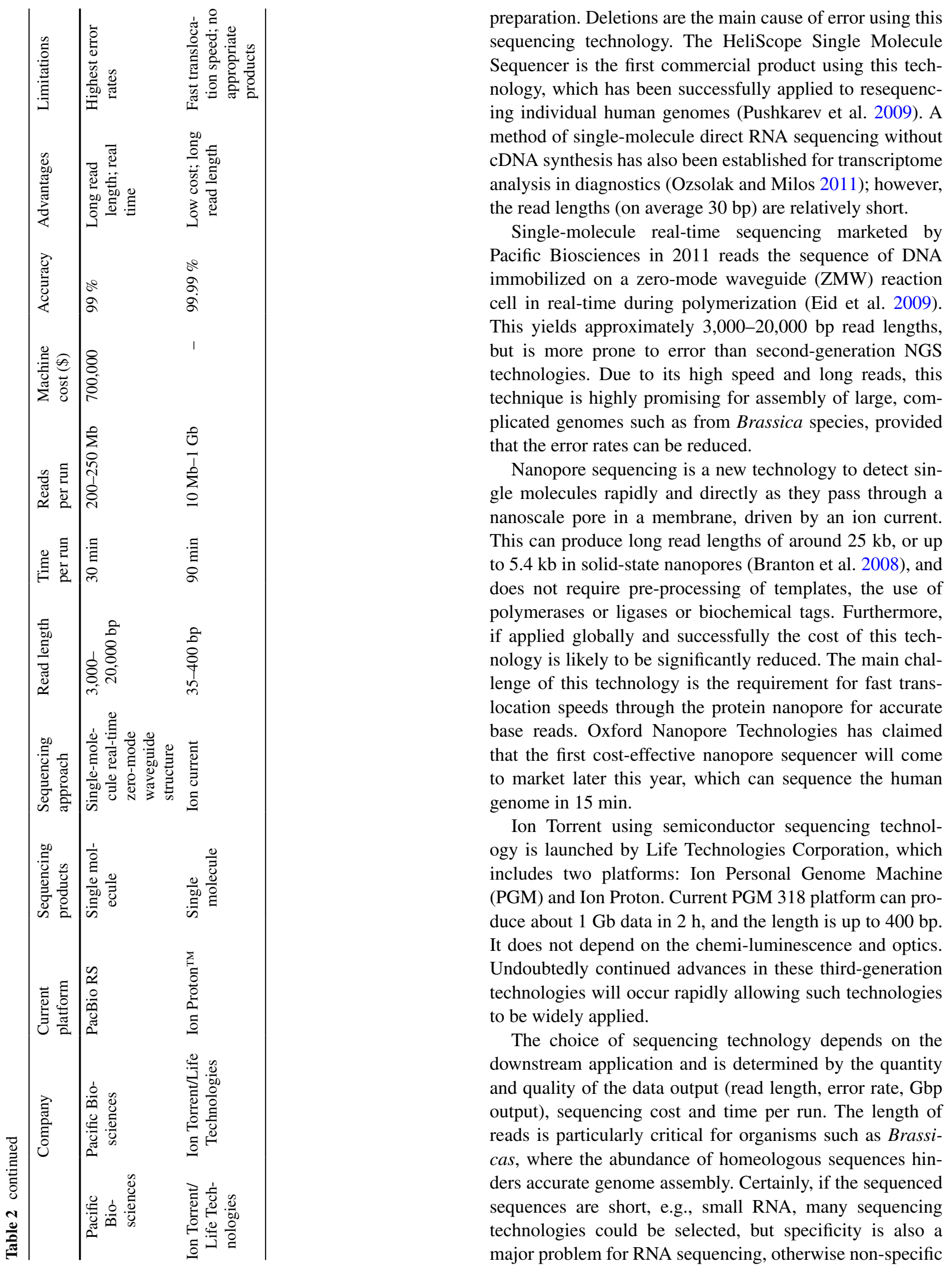


short reads from different loci can map to a single locus and falsify expression quantities.

\section{Complete genome sequencing projects using NGS}

NGS technologies have contributed to the sequencing of complex genomes in the last few years, paving the way for future genomic and genetic research and crop improvement. The combination of traditional and NGS methods can currently provide a method for rapid and cost-effective sequencing of important plant species. For example, the cucumber genome (Cucumis sativus) was sequenced in 2009 with traditional Sanger (3.9x) and Illumina Genome Analyser (GA) NGS reads $(68.3 \times)$. In this way, a total of $243.5 \mathrm{Mb}$ was assembled and 26,682 genes predicted (Huang et al. 2009). The $353.5 \mathrm{Mb}$ watermelon (Citrullus lanatus) genome was obtained at $108.6 \times$ coverage using the Illumina GAII system, and annotated with 23,440 genes (Guo et al. 2012a). Similarly, the barley (Hordeum vulgare; haploid content of $4.98 \mathrm{~Gb}$ ) (Mayer et al. 2012) and sweet orange (Citrus sinensis; $367 \mathrm{Mb}$ generated) genomes were sequenced using Illumina GAIIx technology ( $\mathrm{Xu}$ et al. 2012b). The Illumina GA, Roche 454 and Sanger platforms were used to generate $844 \mathrm{Mb}$ of the complex autotetraploid potato genome using a homozygous doubled-monoploid potato (Xu et al. 2011). A diploid cotton genome was sequenced on the Illumina HiSeq2000 platform at 103.6× resolution (about 775.2 Mb) (Wang et al. 2012b), however, given that most cotton cultivars are tetraploid, novel experimental and computational methods need to be applied for characterization of natural polyploids. Wheat has a complex and huge allohexaploid genome that includes numerous repetitive elements. To simplify genome sequencing and assembly in this species, isolated chromosome arms can be sequenced through NGS technologies, reducing the confounding effects of multiple homologous chromosomes (Berkman et al. 2012). Brenchley et al. (2012) has generated $17 \mathrm{~Gb}$ of the Chinese Spring (CS43) Triticum aestivum (bread wheat), genome with 454 pyrosequencing $(5 \times)$, containing approximately 95,000 genes.

High-coverage and high-quality reference genome sequences are a base or a core of the foundation of omics investigations in of a species, especially polyploidy species. A multinational consortium for Brassica genome sequencing was initiated in 2003, with the initial aim to sequence the diploid $B$. rapa A genome using a BAC tiling path and Sanger technology. Following the development of NGS technology, the B. rapa (Chinese cabbage) v1.1 genome, including 41,174 protein coding genes, was released in 2011 by the international B. rapa Genome Sequencing Project Consortium (Wang et al. 2011b). The completion of $B$. rapa genome provides new insights into genome evolution in Brassicas and, importantly, the first Brassica reference genome. The $B$. oleracea diploid $\mathrm{C}$ genome is the second Brassica crop to undergo genome sequencing, using a combined Illumina and Roche 454 sequencing approach, and is expected to be released later this year.

$B$. napus is an allotetraploid formed from hybridization of B. rapa and B. oleracea and thus possesses a large and complex genome: $\mathrm{AC} 2 \mathrm{n}=19$. Nowadays, genomics investigation of tetraploid B. napus is faced with two critical problems: (1) homeologous regions of high sequence identity between the $\mathrm{A}$ and $\mathrm{C}$ genomes, which interfere with sequence read mapping and thus accurate assembly and correct assignment of homeologous $\mathrm{A}$ and $\mathrm{C}$ chromosomes; (2) Numerous repeat sequences, including simple repeat sequences, minisatellites, satellites and different categories of transposons, which are enriched in B. napus and also hinder mapping and accuracy of assembly. Hence, strategies optimized to study the genome of tetraploid B. napus are required, as follows (Fig. 1):

1. The use of double haploid (DH) B. napus lines, benefiting from advanced microspore culture techniques in many Brassica labs. In these lines, each locus is homozygous, avoiding the interference of allelic variants on sequence assembly. In non-DH heterozygous lines, it is difficult to discriminate the allelic variants within the $\mathrm{A}$ or $\mathrm{C}$ genomes from the homeologous variants. Recently, an RFAPtools pipeline was developed, which was divided into three steps: firstly, a pseudo-reference sequence was assembled; secondly, single-nucleotide polymorphism (SNP) was discovered and genotyped, and finally allelic SNP was discriminated from homeologous loci. It combined with a double digestion RADseq (ddRADseq) approach in a $B$. napus DH population which was developed successfully to discriminate allelic variants from homeologous sequences (Chen et al. 2013).

2. The use of the concomitant genome sequences of $B$. rapa and $B$. oleracea, as the two parental species of $B$. napus, as reference genomes for B. napus genome assembly, followed by careful correction for any large genome rearrangements and variations between these progenitors and B. napus. Indeed, this is currently being applied in the $B$. napus genome sequencing project (Snowdon and Luy 2012).

3. The use of a high-density genetic map, for the accurate mapping of homeologous regions and genome rearrangements relative to reference sequences. Highdensity genetic maps enable the correct ordering of sequence contigs to accurately link physical and genetic maps. In Brassica, the availability of large mapping populations and high-throughput, genome- 
Fig. 1 Strategies for B. napus whole-genome sequencing and future emphasized research on $B$. napus genome. In the sequencing of $B$. napus, double haploid (DH) lines are necessary to avoid the interference of allelic variants on sequence assembling. Diploid progenitor genome and high-density genetic map are also critical for the accurate mapping of homeologous regions and genome rearrangements relative to reference sequences. A combination of BAC-pooling sequencing and whole-genome short-read sequencing will be used to produce a reference sequence of $B$. napus. Expressed sequence tags or BAC sequences sequenced by the Sanger sequencing technique will be used to verify the reference genome. With the production of high-quality reference genomes for Brassica species, future numerous works need be launched

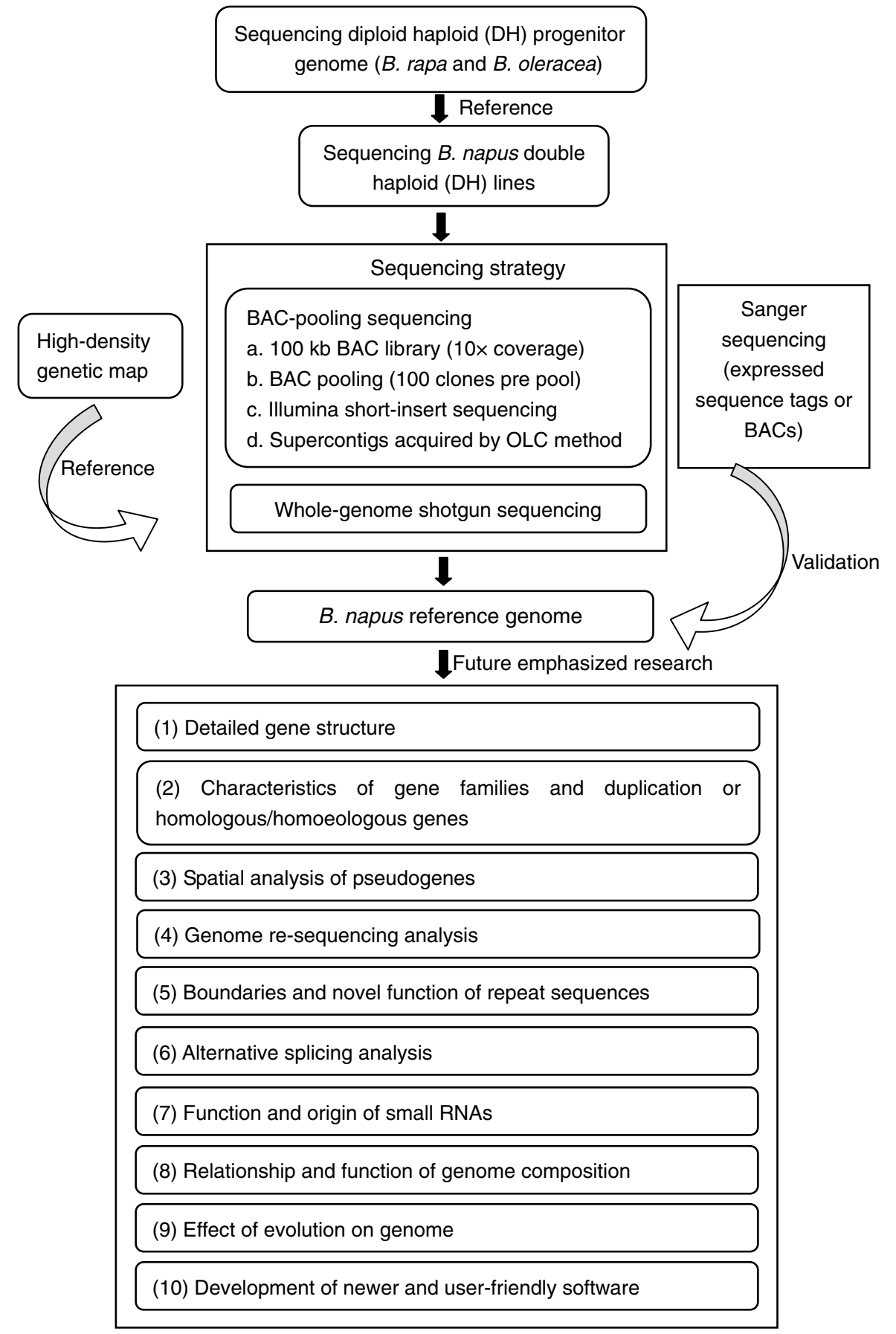

specific genotyping technologies make this highly applicable. For example, Illumina's GoldenGate and Infinium SNP genotyping platforms are currently being developed and applied in Brassica species (Durstewitz et al. 2010), which can detect from 384 to 60, 000 genome-specific SNPs in parallel.

4. The use of a combination of BAC-pool sequencing and whole-genome short-read sequencing for accurate production of a $B$. napus reference genome. In this method, for example, a $100 \mathrm{~kb}$ insert BAC library of $\sim 10,000$ clones $(10 \times$ coverage of $B$. napus $)$ will be evenly and randomly divided into 1,100 pools (100 clones per pool). For each pool, three Illumina shortinsert paired-end sequencing libraries will be constructed, sequenced with $>50 \times$ depth and assembled. Supercontigs can be acquired by merging contigs from each pool using the overlap layout consensus (OLC) method. The redundancy in the assembly can be removed by self-to-self whole-genome alignment and sequencing depth information. Whole-genome 
Illumina libraries (200-bp to 20-kb inserts) then will be constructed with $100 \times$ coverage and used to aid assembly. Overall, BAC supercontigs can be assembled into Scaffolds and then into a reference genome, with the help of high-density genetic map and gap-filling. Finally, expressed sequence tags (EST) or Sangersequenced BACs will be used to verify the reference genome. If these sequences are successfully mapped in the reference genome with a high proportion (e.g., $>99 \%$ ), the reference genome is of high quality.

Sequencing projects for $B$. napus are currently being mediated by 11 research institutes, with the intention to analyze genetic diversity in oilseed rape. Sequencing of the other three cultivated Brassica species, B. nigra, B. juncea and $B$. carinata, are also in the pipeline (See http://canseq. $\mathrm{ca} /)$.

\section{Applications of NGS in Brassica species}

\section{SNP discovery}

SNP density varies between and within species as well as different genomic regions. In rice, SNP density averages one in 147 bp (Subbaiyan et al. 2012), while soybean (Choi et al. 2007) and A. thaliana (Atwell et al. 2010) average $1 / 438$ and $1 / 500 \mathrm{bp}$, respectively. Previously, the application of SNPs was limited because of the high cost of development and detection. SNPs were generally discovered through PCR amplification and Sanger sequencing of genomic regions of interest, or using DNA chips, which were laborious and time consuming. SNPs were also detected with computational tools based on existing EST databases. For instance, a SNP discovery pipeline in barley, wheat, rice and Brassica was developed through analysis of assembled EST sequences (Duran et al. 2009), whereby SNPs are identified by blast comparison or keyword search using AutoSNPdb (http://autosnpdb.appliedbioinformatics. com.au/).

With the advent of NGS technology, the discovery of large numbers of genome-wide SNPs is now highly achievable. Abundant markers can be discovered through amplicon sequencing, transcriptome sequencing, DNA-rich genome sequencing and whole-genome sequencing (Henry et al. 2012). Davey et al. (2011) reviewed genome-wide marker discovery using NGS in both model organisms and non-model species via reduced representation sequencing methods, including reduced representation libraries (RRLs), complexity reduction of polymorphic sequences (CRoPS) and restriction site-associated DNA sequencing (RAD-seq). The development, validation and application of SNPs had been reviewed systematically (Mammadov et al.
2012). Freely available software including SGSAutoSNP (Lorenc et al. 2012) enable rapid, high-throughput, accurate SNP discovery that can be applied to any species with available NGS data. SNP prediction can be complicated by the error rate of NGS and by repetitive or highly homologous regions causing misassembly of short-read lengths. However, the use of paired-end and large-insert NGS sequence reads in genome assembly and the strict quality control parameters in software, such as SGSAutoSNP (Lorenc et al. 2012), can help to minimize non-specific read mapping, and false SNP predictions.

Given that the current public Brassica reference genome is limited to the B. rapa A genome, several methods of detecting SNPs to reduce the size of target sequences were developed, such as transcriptome sequencing, ESTbased sequencing, RAD sequencing and sequence capture using oligonucleotide probes. Trick et al. (2009b) developed a robust method to discover SNPs through transcriptome analysis of the polyploid B. napus cultivars, Tapidor and Ningyou7, using the Illumina platform. In this case, Brassica unigene sequences were used as a reference and aligned with sequence reads using MAQ software to discover SNPs. In total, 23,330-42,593 putative SNPs with different read depth were detected, and $\sim 90 \%$ of the SNPs detected were termed as hemi-SNPs, which were homozygous in one line but heterozygous in the other line (Mammadov et al. 2012). The hemi-SNPs between these two lines could be used for genetic mapping. In addition, $\mathrm{Hu}$ et al. (2012b) discovered 655 putative SNP markers by 454 sequencing of ESTs of two B. napus cultivars: ZY036 and 51070. Similarly, Durstewitz et al. (2010) identified 604 SNPs from ESTs in B. napus (one SNP per $42 \mathrm{bp}$ ), which were then validated using the Illumina GoldenGate SNP genotyping system. However, the primary limitation of SNP discovery from transcriptome sequencing or ESTbased sequencing is the restriction to coding regions, and thus this failed to detect diversity in non-coding regions.

For genome-wide SNP discovery, RAD sequencing technology is a simple, alternative approach for detecting polymorphisms in complex crop genomes by reducing the complexity of the genome. More than 20,000 SNPs and 125 insertions and deletions were indentified in about 113,000 RAD clusters of the B. napus genome sequenced via the Illumina GAIIx system. At the same time, 26 out of 31 SNPs ( $84 \%$ ) in 16 RAD clusters were validated by Sanger sequencing (Bus et al. 2012). This is simple and effective in genetic mapping, but is limited for genomewide association studies (GWAS) due to the small number of markers (Mammadov et al. 2012).

Sequence capture is also a technique that reduces the size of sequenced fragments and identifies homologies in the genome by rapidly tagging a targeted region for sequencing. It not only identifies meta-QTL regions associated 
with traits but also detects the variance of complex traits, like developmental and flowering traits (Snowdon and Luy, 2012). A total of 87 SNPs and 6 Indels were identified based on existing genomic resources in six B. napus varieties (Westermeier et al. 2009). Picho et al. (2010) presented the application of sequence capture in the $B$. napus cultivars Aviso and Montego and identified about 7,000 SNPs, which were useful for QTL mapping and genetic association studies. However, this technology requires a reference sequences for the design of capture probes.

Abundant Illumina read sequences of $B$. napus have been obtained via such complexity reduction methods. Despite combining NGS technology with bioinformatics for SNP discovery, in the allotetraploid B. napus, SNP discovery is currently complicated by the presence of highly homeologous ancestral A and $\mathrm{C}$ genomes and the absence of a reference genome sequence. Polymorphisms are only useful as inter-cultivar SNPs, and must be distinguished from intra-cultivar SNPs between the homeologous A and $\mathrm{C}$ chromosome regions. SNPs derived from both different alleles and homeologues are usually mixed together with above methods. Following the completion of $B$. oleracea genome sequence and de novo $B$. napus genome, comparison to the corresponding diploid species could be used to distinguish these two kinds of SNPs. In addition, Chen et al. (2013) has successfully developed ddRADseq approach, with bioinformatics RFAPtools, to discriminate allelic SNPs from homoeologous sequences in B. napus.

\section{SNP arrays in Brassica}

SNP arrays are the main method for large-scale SNP analysis, which can simultaneously detect millions of SNPs in one reaction. At present there are two main types of SNP array commercialized by Affymetrix and Illumina. The GeneChip Rice 44K SNP Genotyping Array was developed by Affymetrix and used to identify rice varieties and their genetic diversity (McCouch et al. 2010). The 135k Brassica exon Array representing 135,201 genes has been designed for whole-transcript profiling and mapping and for analysis of genome evolution and adaptation in the Brassicaceae family (Love et al. 2010). The Illumina 1M SNP array has the capacity to identify 1 million SNPs. Although the cost of NGS continues to decline, allowing genotyping by sequencing approaches to become more feasible, SNP microarray techniques retain some exclusive advantages. Firstly, they can provide robust analysis techniques using large public reference datasets at reduced when performing the replicated experiments. For Brassica, a public and high-density Illumina SNP array was released in 2012, combining efforts of 16 academic and commercial partners with Illumina Inc (Snowdon and Luy 2012). At present, more than 50,000 SNPs were found to function well in the
Brassica A or C genomes using this SNP panel. This SNP array will offer advantages for GWAS and high-throughput screening of germplasm pools. At the same time, it is effective to identify unique genes or primary expressed genes in the genome (Parkin et al. 2010). However, the SNPs in this array are not evenly distributed across the genome, which may lead to bias in downstream analyses. Therefore, future SNP arrays should be developed based on evenly distributed, genome-wide A genome-specific or $\mathrm{C}$ genomespecific loci. NAM using a SNP array will aim to uncover the basis of yield and stress tolerance in B. napus (Edwards et al. 2013).

\section{Genetic map construction and gene mapping}

Traditional gene mapping methods for most quantitative traits are based on high-density genetic maps, which are constructed using large numbers of molecular markers. NGS followed by the identification of SNPs, and genetically or physically linked groups of SNPs (SNP haplotype) is an ideal tool to perform high-density mapping. $\mathrm{Li}$ et al. (2009) constructed a B. rapa linkage map with ESTbased SNP markers and identified genes associated with flowering time and leaf morphological traits. In addition, the B. napus SNP linkage map was constructed based on SNPs discovered by Illuminsa sequencing (Bancroft et al. 2011). An integrated genetic map containing 5,764 SNPs and 1,603 PCR markers in B. napus was made through SNP genotyping, to produce a higher density, more accurate map than those previously available (Delourme et al. 2013). These SNP maps are applicable to researching complex traits and they are also critical to the assembly of scaffolds in whole-genome sequencing.

Sequencing mixed DNA pools from lines with extreme trait variants in a population enable development of novel molecular markers linked to genes of interest. This is more rapid than gene identification and cloning using conventional methods. Mapping-by-sequencing based on resequencing of bulked segregants using SHOREmap software package (http://1001genomes.org/software/shoremap.html) can identify candidate genes, but it is usually limited by the requirement of a completed genome as reference. Galvao et al. (2012) developed a synteny-based method to perform mapping-by-sequencing with few markers in species where whole-genome sequences were unavailable but transcriptome assemblies were available. This was validated to be effective for genetic mapping in A. thaliana and its distant relative $B$. rapa. Due to the complexity of the tetraploid Brassica genome, at present the diploid progenitor $B$. rapa genome can be used as a reference for candidate gene identification (Tollenaere et al. 2012). A total of 70 SNPs associated with rapeseed pod shatter resistance were discovered and a major QTL was found on chromosome A9 through 
the combination of NGS and BSA (Hu et al. 2012a). Highdensity genetic maps constructed by NGS technology is effective for the identification of SNP markers linked to target traits and can narrow the confidence intervals of QTLs of interest into smaller regions.

\section{Association mapping}

Traditional linkage mapping identifies the relationships between traits and linked markers following recent recombination events in biparental, structured populations. Meanwhile association mapping, also named as linkage disequilibrium mapping, can be used to identify genes linked with natural variation in populations. Although association mapping can be hampered by confounding population structure, leading to false positives and false negatives due to spurious correlations (Zhao et al. 2007), QTL mapping by association analysis can be a valid approach, for phenological, morphological and quality traits, e.g., in winter rapeseed (Honsdorf et al. 2010). Zhao et al. (2010) constructed a $B$. rapa core collection of 239 accessions for association mapping studies. The genetic loci for oil content, identified in association mapping, were also located within QTL intervals of linkage mapping in B. napus (Zou et al. 2010).

Candidate gene sequencing (CGS) and whole-genome scanning (WGS) of natural populations are the two main methods of association mapping. NGS offers abundant molecular markers, producing large quantities of genotyping data. In situations where no reference genomic sequence is available, WGS was carried out by applying SNP markers to gene expression variation data generated by RNA sequencing (Stower 2012). Given that the polyploid nature of $B$. napus complicates the assembly of genome sequences, and no reference genome is currently available, associative transcriptomics was proposed as a method to link molecular markers with trait variation indentified in $B$. napus (Harper et al. 2012). This study found that QTLs for the glucosinolate content of seeds were located on genomic regions showing presence-absence variation for the gene of interest in the population. This research offers for a model pipeline for association genetics in species with complex genomes.

However, common association mapping has reduced ability to detect minor-effect QTLs. Hence, the approach of NAM was proposed to solve the problem of various minor-effect QTLs. A NAM population is composed of several recombination inbred line (RIL) families that are derived from the cross of diverse inbred lines to a single reference inbred line. This combines the advantages of linkage analysis and association mapping, enabling analysis of recent recombination events from segregation progeny and historic recombination events from parental inbred lines. NAM can also produce high-resolution mapping with high allele richness for QTL detection, for example, for quantitative resistance traits (Poland et al. 2011) and genetic compositions of complex traits (Cook et al. 2011). The construction of NAM populations of Brassica is underway for genome-wide association analysis of complex traits (Cowling and Balazs 2010). But the disadvantage of this method is that the construction of NAM population is time-consuming, e.g., the hybrids between more than one parental line and the reference line were self-fertilized for six generations, which is a long process.

\section{Transcriptome analysis in Brassicas}

Transcriptome sequencing is an alternative approach to reduce the size of test sequences but obtain almost equal gene information. In particular, NGS provided a new tool for transcriptome sequencing even where genomic sequence information is not available. The first technology used widely in transcriptome sequencing was Roche 454, due to its long sequence reads. Subsequently, the appearance of Illumina and SOLiD technologies, with highthroughput and relatively short-read lengths, dominated transcriptome sequencing in Brassica (Table 3). Bancroft et al. (2011) sequenced the leaf transcriptome of $B$. napus as well as its progenitor species, B. rapa and B. oleracea using Illumina NGS. The SNP linkage map comprising 23,037 markers in B. napus was constructed after the analysis of sequence variation in these species. Transcriptome sequencing with NGS can produce much important information in relation to gene discovery (Higgins et al. 2012), causal SNP discovery within genes, and the discovery of genomic structural loci, for instance, alternative splicing determinants (AS). Detailed information about SNP discovery is delineated above.

\section{Digital gene expression}

In this system, the transcript levels of given genes are quantified in silico by sequence read profiling, also termed digital gene expression. This aims to determine the level of gene expression in particular biological processes, developmental stages and following various treatments, based purely on NGS read abundance for a specific locus. Previously, DNA microarray technology was used for this, whereby the hybridization intensity determined the levels of gene expression. Trick et al. (2009a) developed a public Brassica microarray resource, using the assembly of about 800,000 EST sequences, to analyze gene expression in resynthesised B. napus lines and their parents. However, important limitations of this method are (1) sequence information is required, (2) the cost is high, (3) the results can be too complex and inconsistent to clearly interpret and (4) the candidate genes are difficult to determine (Table 4). 
Table 3 The main application of NGS in Brassica

\begin{tabular}{|c|c|c|c|c|}
\hline Application & Details & Species & NGS technology & Reference \\
\hline \multicolumn{5}{|l|}{ SNP discovery } \\
\hline Transcriptome sequencing & $\begin{array}{l}\text { About } 40,000 \text { putative SNP were } \\
\text { discovered in Tapidor and } \\
\text { Ningyou } 7\end{array}$ & B. napus & Illumina/Solexa & Trick et al. (2009a) \\
\hline \multirow[t]{2}{*}{ Sequencing of ESTs } & $\begin{array}{l}655 \text { putative SNP markers were } \\
\text { discovered in cultivars ZY036 } \\
\text { and } 51070\end{array}$ & B. napus & 454 sequencing & Hu et al. (2012a) \\
\hline & 604 SNPs were discovered & B. napus & Illumina/Solexa & Durstewitz et al. (2010) \\
\hline RAD sequencing & 20,000 SNPs were indentified & B. napus & Illumina GAIIx system & Bus et al. (2012) \\
\hline \multirow[t]{2}{*}{ Sequence capture } & $\begin{array}{l}87 \text { SNPs and } 6 \text { Indels were identi- } \\
\text { fied in six rapeseed varieties }\end{array}$ & B. napus & - & $\begin{array}{l}\text { Westermeier et al. } \\
\text { (2009) }\end{array}$ \\
\hline & $\begin{array}{l}\text { 7,000 SNPs were identified, } \\
\text { respectively, in B. napus culti- } \\
\text { vars Aviso and Montego }\end{array}$ & B. napus & - & Edwards et al. (2013) \\
\hline \multicolumn{5}{|c|}{ Genetic mapping and gene location } \\
\hline SNP haplotypes & $\begin{array}{l}\text { The SNP linkage map was con- } \\
\text { structed }\end{array}$ & B. napus & Illumina/Solexa & Bancroft et al. (2011) \\
\hline NGS-BSA & $\begin{array}{l}\text { A major QTL associated with } \\
\text { rapeseed pod shatter resistance } \\
\text { were found }\end{array}$ & B. napus & Illumina/Solexa & Hu et al. (2012a) \\
\hline \multicolumn{5}{|l|}{ Association mapping } \\
\hline Associative transcriptomics & $\begin{array}{l}\text { Finding deletion genomic regions } \\
\text { in QTLs of glucosinolate con- } \\
\text { tent of seeds }\end{array}$ & B. napus & Illumina/Solexa & Harper et al. (2012) \\
\hline \multicolumn{5}{|l|}{ Transcriptome analysis } \\
\hline Leaf transcriptome analysis & 23,037 markers were identified & B. napus & Illumina/Solexa & Bancroft et al. (2011) \\
\hline \multirow[t]{2}{*}{ Tag profiling } & $\begin{array}{l}1,092 \text { genes were discovered } \\
\text { relating with water deficit }\end{array}$ & Chinese cabbage & Illumina/Solexa & Yu et al. (2012a) \\
\hline & $\begin{array}{l}\text { Over seven million ESTs were } \\
\text { generated in four oilseeds }\end{array}$ & B. napus & 454 pyrosequencing & $\begin{array}{l}\text { Troncoso-Ponce et al. } \\
\text { (2011) }\end{array}$ \\
\hline \multirow[t]{2}{*}{ Genes discovery } & $\begin{array}{l}\text { Genes related with stem swelling } \\
\text { were discovered }\end{array}$ & B. juncea & Illumina/Solexa & Sun et al. (2012) \\
\hline & $\begin{array}{l}\text { Genes related with chloroplast } \\
\text { were discovered }\end{array}$ & B. oleracea & Illumina/Solexa & Zhou et al. (2011b) \\
\hline Alternative splicing & $\begin{array}{l}\text { AS patterns are common and } \\
\text { change rapidly after polyploidi- } \\
\text { zation, greatly contributing to } \\
\text { the transcriptome shock }\end{array}$ & B. napus & - & Zhou et al. (2011a) \\
\hline \multicolumn{5}{|l|}{ MicroRNA } \\
\hline \multirow[t]{4}{*}{ MiRNA discovery } & $\begin{array}{l}50 \text { conserved miRNAs, } 11 \text { new } \\
\text { miRNAs and some miRNA } \\
\text { targets were identified in differ- } \\
\text { ent oil content at developmental } \\
\text { stage }\end{array}$ & B. napus & Illumina/Solexa & Zhou et al. (2011a) \\
\hline & $\begin{array}{l}228 \text { novel and } 321 \text { conserved } \\
\text { miRNAs were found }\end{array}$ & Chinese cabbage & Illumina/Solexa & Wang et al. (2012a) \\
\hline & $\begin{array}{l}33 \text { conserved and } 19 \text { new mRNA } \\
\text { targets were found through } \\
\text { degradome sequencing }\end{array}$ & B. napus & Illumina/Solexa & Xu et al. (2012a) \\
\hline & $\begin{array}{l}59 \text { B. napus miRNA families } \\
\text { were found and were associated } \\
\text { with seed development } \\
\text { and energy storage }\end{array}$ & B. napus & Illumina & Korbes et al. (2012) \\
\hline
\end{tabular}


Table 3 continued

\begin{tabular}{lllll}
\hline Application & Details & Species & NGS technology & Reference \\
\hline $\begin{array}{l}\text { The differential expression of } \\
\text { miRNAs }\end{array}$ & $\begin{array}{c}\text { Heavy metal cadmium-regulated } \\
\text { miRNAs were identified } \\
\text { MiRNAs responded to heat stress } \\
\text { were identified } \\
\text { MiRNAs responded to arsenic } \\
\text { stress were identified }\end{array}$ & B. napus & Illumina/Solexa & Zhou et al. (2012) \\
& Buncea & Illumina/Solexa & $\begin{array}{c}\text { Wang et al. (2011a), Yu } \\
\text { et al. (2012b) } \\
\text { Srivastava et al. (2012) }\end{array}$ \\
\hline
\end{tabular}

Table 4 Advantages and disadvantages of four methods of gene expression analysis

\begin{tabular}{|c|c|c|}
\hline & Advantages & Disadvantages \\
\hline DNA microarray & High throughput & $\begin{array}{l}\text { Need to know gene sequences and design } \\
\text { probe sequences; high cost; difficult to } \\
\text { identify candidate genes }\end{array}$ \\
\hline Serial analysis of gene expression (SAGE) & $\begin{array}{l}\text { Do not need to know sequences of genes; no hybridiz- } \\
\text { ing; identifying new genes }\end{array}$ & $\begin{array}{l}\text { Requiring quantity of RNA; high cost; } \\
\text { considerable sequencing reactions }\end{array}$ \\
\hline $\begin{array}{l}\text { Massively parallel signature sequencing } \\
\text { (MPSS) }\end{array}$ & $\begin{array}{l}\text { Do not need to know sequences of genes; creating } \\
\text { digital data; producing more sequences }\end{array}$ & $\begin{array}{l}\text { Requiring quantity of RNA; high cost; } \\
\text { relatively new technique }\end{array}$ \\
\hline Digital gene expression & High throughput; discriminating homologous genes & Producing quantity of data; high cost \\
\hline
\end{tabular}

Serial analysis of gene expression (SAGE) (Obermeier et al. 2009) and massively parallel signature sequencing (MPSS) are another two traditional approaches for RNA sequencing. SAGE requires considerable sequencing reactions at high cost, while MPSS requires large quantities of mRNA $(2.5-5 \mu \mathrm{g})$ to perform transcriptome analysis. Digital gene expression profiling based on NGS is becoming increasingly widely used in Brassica transcriptomics. This technique can discriminate homeologous gene expression in polyploids by comparing with the reference unigene sequences from diploid representative genomes (Higgins et al. 2012). Yu et al. (2012a) analyzed gene expression in a drought model of Chinese cabbage using Illumina NGS technology and found 1,092 genes associated with response to water deficit. In addition, over seven million ESTs were generated from four oilseeds including B. napus at four stages of development using 454 pyrosequencing, which can assist future functional and comparative genomic researches (Troncoso-Ponce et al. 2011). These suggest that digital gene expression has been of value in large-scale analysis of gene expression.

Gene discovery

In cases where genome sequences of species exist, unigenes can be obtained by assembly of RNA sequence reads (Wang et al. 2010; Chen et al. 2011). The transcriptome of tumourous stem mustard (B. juncea var. tumida Tsen et Lee) was sequenced by Illumina short-read technology, identifying 146,265 unigenes, in which 1,042 significantly expressed genes were associated with stem swelling and development (Sun et al. 2012). Zhou et al. (2011b) identified 7,155 genes related to chloroplast development in $B$. oleracea, determined the role of regulatory genes by RNA sequencing with the Illumina Genome Analyzer II system, and discovered 1,600 up-regulated genes in light signaling pathways in green curd tissue. mRNA sequencing with NGS is not only a powerful tool for the identification of the genetic basis of the certain traits but will also help to accelerate gene expression and functional analysis. Numerous related genes were discovered, but major genes and their function were not validated in most studies. Major genes can be found through previous QTL mapping results, which had been made extensively, and then can be identified by real-time quantitative PCR or resequencing candidate gene PCR products.

Mutational sites can be identified directly by deep sequencing with NGS technologies. Short-read sequencing has been successfully applied in the identification of frame shift mutations in A. thaliana, with high specificity and high sensitivity, without prior gene information (Laitinen et al. 2010). Such mutant screens can be applied to the Brassica genome. Mutations in larger targeted regions or whole exomes of mutant populations were detected in B. napus using Illumina sequencing (Plant and Animal Genome meeting) (Sidebottom et al. 2012).

Alternative splicing (AS)

AS refers to the various ways that splicing introns in one eukaryotic pre-mRNA may result in several different mRNAs and protein products. AS is important for 
determining the complexity of genes, and appears to occur in about $33 \%$ of all rice genes (Zhang et al. 2010) with possibility of reaching $60 \%$ in different tissues, ambient conditions or developmental stages (Syed et al. 2012). In Brassica, changes in gene characteristics and AS patterns are common after polyploidization, and AS changes greatly contribute to transcriptome shock, whereby extensive changes in gene expression pattern (Zhou et al. 2011a). However, dynamic changes in AS in whole genomes under different conditions or stresses, and the varied role of AS patterns in the evolution of plant species are still unknown. Akhunov et al. (2013) discovered a high level of AS pattern divergence in homeologous genes of wheat. This indicates that the dynamitic changes of AS in polyploidization, different developmental stages, different tissues or different treatments are a promising research direction in Brassica species. With the advent of B. napus genome sequencing, the AS events and the role of AS in polyploidization will be identified.

\section{MicroRNA}

MicroRNAs (miRNA) are a class of small non-coding RNA of about 18-30 nucleotides that regulate gene expression in plant development and response to environmental stress. miRNAs are wildly expressed in plants and animals, even in mosses and fungi, because of their conserved functions in developmental processes. These small RNAs are produced from hairpin-shaped precursors (pri-miRNA) with the help of the endonuclease, DCL1 (DICER-LIKE 1). In the past, the discovery of novel miRNAs depended on cloning and sequencing of individual miRNAs, which could not be distinguished from other non-coding RNAs, such as rRNAs or tRNAs. Emerging microarray technology can detect miRNA genotypes on a large scale but is limited in the capacity to detect novel miRNAs. NGS technology opens new opportunities for novel miRNA discovery and profiling, as well as the identification of miRNA targets. By analyzing small RNA profiles of the embryos of $B$. napus with different oil contents at different developmental stages, a total of 50 conserved miRNAs, 11 new miRNAs and some miRNA targets were identified (Zhao et al. 2012). Korbes et al. (2012) detected 59 B. napus miRNA families at different seed developmental stages using Illumina sequencing, in which 13 were novel miRNA families. The putative functions of miRNA target genes were associated with seed development and energy storage. In Chinese cabbage, 228 novel and 321 conserved miRNAs were found using Illumina NGS technology, which laid the foundation for further study of miRNA regulation mechanisms (Wang et al. 2012a). However, these studies only focused on the discovery of miRNAs, but the core miRNAs and their role in B. napus were less studied. Numerous works are still required to determine the function of miRNA in the polyploidization of $B$. napus. In addition, long non-coding RNA is a novel field and not reported in Brassica crops up to now. It will become a new star like small RNAs.

Noticeably, degradome sequencing is a vital method for identification of miRNA targeted mRNAs. Traditionally, target mRNA identification relies on computational prediction and subsequent experimental verification, which cannot only lead to inaccurate results but is also time-consuming. Degradome sequencing technology acts directly on the $3^{\prime}$-end of mRNA fragments with a poly-A tail, which are complementary with an miRNA, to figure out the target gene. Recently, Xu et al. (2012a) performed whole-mRNA degradome sequencing of $B$. napus and found 33 conserved and 19 new mRNA targets, providing for the first platform for miRNA regulation functional research in Brassica. This exploited the mixed mRNA samples from different tissues, and abundant targets were detected. But degradome sequencing can only detect the targets regulated by the transcript cleavage model, not by translational repression.

The differential expression of miRNAs in different developmental stages and diverse treatments is a main application of small RNA sequencing. Heavy metal cadmium-regulated miRNAs of $B$. napus were identified by Illumina sequencing technology and novel targets were found to participate in response to cadmium (Zhou et al. 2012). In B. rapa, miRNAs responding to heat stress were also found to play a key role in response to heat (Yu et al. 2012b; Wang et al. 2011a). Srivastava et al. (2012) showed via microarray profiling that miRNAs play a great role in response to arsenic stress in $B$. juncea. Indeed, both genetic and epigenetic factors, including heritable DNA methylation profiles and corresponding small RNA activities, contribute to phenotypic traits. Therefore, a combination of genome sequencing, single-base methylation sequencing, transcriptome expression analysis and small RNA analysis will form the basis of complex trait research.

Marker-assisted selection (MAS) and genome selection in breeding

It is essential to understand the association between phenotypic variation of traits of interest and their intrinsic genetic variation at the DNA sequence level in crop improvement breeding. Molecular markers can be used to accelerate the process of traditional breeding. In backcross breeding, selection toward a genetic background is a critical step in deciding the number of backcrosses with the recurrent parent. MAS can accelerate this process by tracking target genes with linked markers to eliminate linkage drag. Although the idea of MAS has been put forward for many years, successful breeding outcomes are rare and its use is usually blocked by most quantitative 
Fig. 2 The application of NGS in Brassica crop breeding
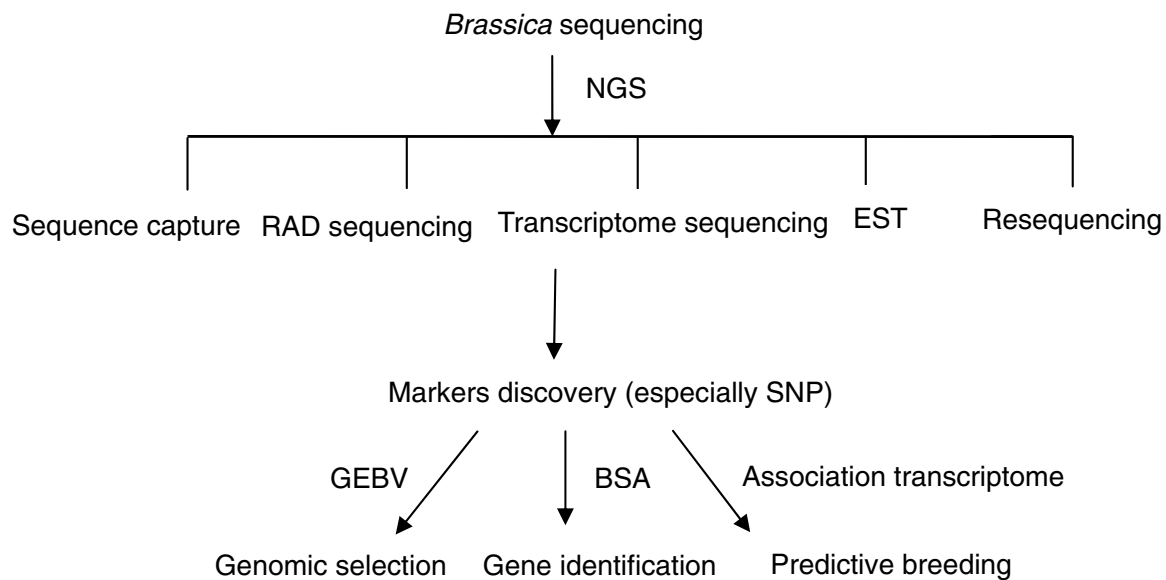

RAD sequencing: restriction-site associated DNA sequencing;

GEBV: genomic estimated breeding value;

BSA: bulked segregant analysis

traits, because only a small number of markers associated with a phenotype are identified and genotyping cost is relatively high. Another method, termed genomic selection, is proposed to solve such problems in breeding, and estimates the values of individual lines with high density markers across the whole genome (Fig. 2). Heffner et al. (2009) made a simulation between the true breeding value and genomic estimated breeding value (GEBV) and the correlation coefficient between them reached 0.85 , which indicated that GEBV could be used to estimate the true breeding value. Genomic selection is an ideal tool to select lines of interest with markers alone, circumventing the need for costly and time-consuming phenotyping of breeding lines. The accuracy with genomic selection using ridge regression-best linear unbiased prediction was higher than conventional MAS via composite interval mapping (Guo et al. 2012b). Likewise in Brassica, genomic selection will accelerate breeding cycles with the aim to meet the increasing demands of production. However, the lack of valuable markers linked to important agronomic traits has negatively impacted research into genomic selection in Brassica. In addition, it is a challenge to develop homeologous gene-specific markers because it is very difficult to select efficient loci which distinguishes different homeologous genes with high similarity.

\section{Future emphasized research area of NGS in Brassica}

With the production of high-quality reference genomes for Brassica species, the stage is set for numerous genomics studies. For Brassica crops, we have emphasized some fields that require further analysis (Fig. 1). These are:
1. Detailed gene structure. The start and end of the promoter (including transcription factor binding sites (TFBS, untranslated regions (UTR) (including 5-end and 3-end UTRs), coding regions, introns, exons and even enhancers of each gene should be determined.

2. Characteristics of gene families and duplicated genes. Classification, evolution and transcriptional analysis of gene families and duplicated or homologous/homeologous genes should be done.

3. Spatial analysis of pseudogenes. The position, number and role of pseudogenes and their homologous/homeologous genes are worth investigation since they may play a role in species polyploidization and possibly the generation of small RNAs to regulate other genes (Guo et al. 2009).

4. Genome resequencing analysis. Genome resequencing should be done for SNP and Indel discovery and analysis of the position, copy number variation (CNV), and phylogeny of genes among different materials for analysis of species evolution or domestication. A haplotype map or genome variation map should also be produced.

5. Boundaries and novel function of repeat sequences. The boundaries of different kinds of repeat sequences especially transposon sequences should be defined. Though many tools are used to resolve this problem, there are no suitable tools that can adjust the prediction strategies according to the specificity of individual species (Myrick and Gelbart 2007). For Brassica crops enriched for repeat sequences, their boundary definition and classification is a big problem. In addition, the novel functions of repeat sequences should be clarified. For example, can some transposons gen- 
erate small RNAs that regulate other coding genes? Which transposons are active, or can be induced to become active when environment changes? What roles do they play in maintaining species propagation?

6. Alternative splicing analysis. Alternative splicing events, new genes and fusion genes should be identified and resolved by high depth transcriptome sequencing.

7. Function and origin of small RNAs. The function of numerous small RNAs need be determined. Nowadays, NGS predicts or offers considerable miRNAs in Brassica species, but their functions, origins, generation mechanisms and variation/evolution remain unclear.

8. Relationship and function of genome composition. What are the relationship of different genome composition and their functions? Whether the genes, transposons and small RNAs are unevenly distributed (e.g., gene cluster, transposons cluster and small RNA cluster)? Wei et al. (2013) found that nested-LTR retrotransposons were distributed in six Brassica BAC clones, and these played great role in the formation of centromeres. If so, how does evolution or domestication affect this phenomenon?

9. Effect of evolution on genome. How does evolution, domestication or artificial selection shape genome structure, distribution and structural variation of different composites in the genome, and alter gene function, transposons and small RNAs?

10. Development of newer and user-friendly software. Although the cost of NGS continues to decline, it can still be prohibitive for analysis of large collections of various accessions. Meanwhile, vast amounts of data are generated from NGS, but errors still exist and intensive, professional computational tools are needed to store and deal with these large amounts of data. Currently, analysis tools are only mastered by a few trained professionals. This can be a limitation for obtaining enough useful sequence information from a lot of sequence reads. Newer, user-friendly software needs to be developed and applied in order to match the fast development of sequencing technology.

\section{Outlook}

Improvements in third-generation sequencing technology are promising for directly acquiring long sequence reads to reduce the complexity and cost of genome assembly. It is worth highlighting that the study of all species can be individualized to reveal the role of gene expression by high-throughput sequencing of respective tissue and organ, or individual plant response to different treatments and environment. The human genome project was completed in 2003 and had made considerable progress in the application of NGS technology in disease diagnosis and gene functional analyses. In Brassicas, information gained from the completed genome of B. rapa, for instance molecular markers, can be transferred to other Brassica crops. Xu et al. (2010) constructed an integrated genetic map of the A genome in B. napus using SSR markers originating from $B$. rapa sequenced BACs. In the near future, the release of the $B$. olerace and $B$. napus genomes will greatly accelerate the large-scale application of NGS in Brassica species. This has important implications for downstream functional genomic and epigenetic analyses of the control of important agronomical traits in Brassicas and other complex crop species.

\section{References}

Akhunov E, Sehgal S, Liang H, Wang S, Akhunova A, Kaur G, Li W, Forrest K, See D, Simkova H, Ma Y, Hayden M, Luo M, Faris J, Dolezel J, Gill B (2013) Comparative analysis of syntenic genes in grass genomes reveals accelerated rates of gene structure and coding sequence evolution in polyploid wheat. Plant Physiol 161(1):252-265

Al-Dous EK, George B, Al-Mahmoud ME, Al-Jaber MY, Wang $\mathrm{H}$, Salameh YM, Al-Azwani EK, Chaluvadi S, Pontaroli AC, DeBarry J, Arondel V, Ohlrogge J, Saie IJ, SulimanElmeer KM, Bennetzen JL, Kruegger RR, Malek JA (2011) De novo genome sequencing and comparative genomics of date palm (Phoenix dactylifera). Nat Biotechnol 29(6): $521-527$

Arumuganathan K, Earle ED (1991) Nuclear DNA content of some important plant species. Plant Mol Biol Report 9(3):208-218

Ashelford K, Eriksson ME, Allen CM, D'Amore R, Johansson M, Gould P, Kay S, Millar AJ, Hall N, Hall A (2011) Full genome re-sequencing reveals a novel circadian clock mutation in Arabidopsis. Genome Biol 12(3):R28

Atwell S, Huang YS, Vilhjalmsson BJ, Willems G, Horton M, Li Y, Meng D, Platt A, Tarone AM, Hu TT, Jiang R, Muliyati NW, Zhang X, Amer MA, Baxter I, Brachi B, Chory J, Dean C, Debieu M, de Meaux J, Ecker JR, Faure N, Kniskern JM, Jones JD, Michael T, Nemri A, Roux F, Salt DE, Tang C, Todesco M, Traw MB, Weigel D, Marjoram P, Borevitz JO, Bergelson J, Nordborg M (2010) Genome-wide association study of 107 phenotypes in Arabidopsis thaliana inbred lines. Nature 465(7298):627-631

Aversano R, Ercolano MR, Caruso I, Fasano C, Rosellini D, Carputo D (2012) Molecular tools for exploring polyploid genomes in plants. Int J Mol Sci 13(8):10316-10335

Bancroft I, Morgan C, Fraser F, Higgins J, Wells R, Clissold L, Baker D, Long Y, Meng J, Wang X, Liu S, Trick M (2011) Dissecting the genome of the polyploid crop oilseed rape by transcriptome sequencing. Nat Biotechnol 29(8):762-766

Baranzini SE, Mudge J, van Velkinburgh JC, Khankhanian P, Khrebtukova I, Miller NA, Zhang L, Farmer AD, Bell CJ, Kim RW, May GD, Woodward JE, Caillier SJ, McElroy JP, Gomez R, Pando MJ, Clendenen LE, Ganusova EE, Schilkey FD, Ramaraj T, Khan OA, Huntley JJ, Luo S, Kwok PY, Wu TD, Schroth GP, Oksenberg JR, Hauser SL, Kingsmore SF (2010) Genome, 
epigenome and RNA sequences of monozygotic twins discordant for multiple sclerosis. Nature 464(7293):1351-1356

Berkman PJ, Lai KT, Lorenc MT, Edwards D (2012) Next-generation sequencing applications for wheat crop improvement. Am J Bot 99(2):365-371

Branton D, Deamer DW, Marziali A, Bayley H, Benner SA, Butler T, Di Ventra M, Garaj S, Hibbs A, Huang X, Jovanovich SB, Krstic PS, Lindsay S, Ling XS, Mastrangelo CH, Meller A, Oliver JS, Pershin YV, Ramsey JM, Riehn R, Soni GV, TabardCossa V, Wanunu M, Wiggin M, Schloss JA (2008) The potential and challenges of nanopore sequencing. Nat Biotechnol 26(10):1146-1153

Brenchley R, Spannagl M, Pfeifer M, Barker GL, D'Amore R, Allen AM, McKenzie N, Kramer M, Kerhornou A, Bolser D, Kay S, Waite D, Trick M, Bancroft I, Gu Y, Huo N, Luo MC, Sehgal S, Gill B, Kianian S, Anderson O, Kersey P, Dvorak J, McCombie WR, Hall A, Mayer KF, Edwards KJ, Bevan MW, Hall N (2012) Analysis of the bread wheat genome using whole-genome shotgun sequencing. Nature 491(7426):705-710

Buggs RJA, Renny-Byfield S, Chester M, Jordon-Thaden IE, Viccini LF, Chamala S, Leitch AR, Schnable PS, Barbazuk WB, Soltis PS, Soltis DE (2012) Next-generation sequencing and genome evolution in allopolyploids. Am J Bot 99(2):372-382

Bus A, Hecht J, Huettel B, Reinhardt R, Stich B (2012) High-throughput polymorphism detection and genotyping in Brassica napus using next-generation RAD sequencing. BMC Genomics 13(1):281

Chen S, Luo H, Li Y, Sun Y, Wu Q, Niu Y, Song J, Lv A, Zhu Y, Sun C, Steinmetz A, Qian Z (2011) 454 EST analysis detects genes putatively involved in ginsenoside biosynthesis in Panax ginseng. Plant Cell Rep 30(9):1593-1601

Chen X, Li X, Zhang B, Xu J, Wu Z, Wang B, Li H, Younas M, Huang L, Luo Y, Wu J, Hu S, Liu K (2013) Detection and genotyping of restriction fragment associated polymorphisms in polyploid crops with a pseudo-reference sequence: a case study in allotetraploid Brassica napus. BMC Genomics 14:346

Choi IY, Hyten DL, Matukumalli LK, Song Q, Chaky JM, Quigley CV, Chase K, Lark KG, Reiter RS, Yoon MS, Hwang EY, Yi SI, Young ND, Shoemaker RC, van Tassell CP, Specht JE, Cregan PB (2007) A soybean transcript map: gene distribution, haplotype and single-nucleotide polymorphism analysis. Genetics 176(1):685-696

Cokus SJ, Feng S, Zhang X, Chen Z, Merriman B, Haudenschild CD, Pradhan S, Nelson SF, Pellegrini M, Jacobsen SE (2008) Shotgun bisulphite sequencing of the Arabidopsis genome reveals DNA methylation patterning. Nature 452(7184):215-219

Cook JP, McMullen MD, Holland JB, Tian F, Bradbury P, Ross-Ibarra J, Buckler ES, Flint-Garcia SA (2011) Genetic architecture of maize kernel composition in the nested association mapping and inbred association panels. Plant Physiol 158(2):824-834

Cowling WA, Balazs E (2010) Prospects and challenges for genomewide association and genomic selection in oilseed Brassica species. Genome 53(11):1024-1028

Davey JW, Hohenlohe PA, Etter PD, Boone JQ, Catchen JM, Blaxter ML (2011) Genome-wide genetic marker discovery and genotyping using next-generation sequencing. Nat Rev Genet 12(7):499-510

Delourme R, Falentin C, Fomeju BF, Boillot M, Lassalle G, Andre I, Duarte J, Gauthier V, Lucante N, Marty A, Pauchon M, Pichon JP, Ribiere N, Trotoux G, Blanchard P, Riviere N, Martinant JP, Pauquet J (2013) High-density SNP-based genetic map development and linkage disequilibrium assessment in Brassica napus L. BMC Genomics 14:120

Dowen RH, Pelizzola M, Schmitz RJ, Lister R, Dowen JM, Nery JR, Dixon JE, Ecker JR (2012) Widespread dynamic DNA methylation in response to biotic stress. Proc Natl Acad Sci USA 109(32):E2183-E2191

Duran C, Appleby N, Clark T, Wood D, Imelfort M, Batley J, Edwards D (2009) AutoSNPdb: an annotated single nucleotide polymorphism database for crop plants. Nucleic Acids Res 37(Database issue):D951-D953

Durstewitz G, Polley A, Plieske J, Luerssen H, Graner EM, Wieseke R, Ganal MW (2010) SNP discovery by amplicon sequencing and multiplex SNP genotyping in the allopolyploid species Brassica napus. Genome 53(11):948-956

Edwards D, Batley J (2010) Plant genome sequencing: applications for crop improvement. Plant Biotechnol J 8(1):2-9

Edwards D, Batley J, Snowdon RJ (2013) Accessing complex crop genomes with next-generation sequencing. Theor Appl Genet 126(1):1-11

Eid J, Fehr A, Gray J, Luong K, Lyle J, Otto G, Peluso P, Rank D, Baybayan P, Bettman B, Bibillo A, Bjornson K, Chaudhuri B, Christians F, Cicero R, Clark S, Dalal R, Dewinter A, Dixon J, Foquet M, Gaertner A, Hardenbol P, Heiner C, Hester K, Holden D, Kearns G, Kong X, Kuse R, Lacroix Y, Lin S, Lundquist P, Ma C, Marks P, Maxham M, Murphy D, Park I, Pham T, Phillips M, Roy J, Sebra R, Shen G, Sorenson J, Tomaney A, Travers K, Trulson M, Vieceli J, Wegener J, Wu D, Yang A, Zaccarin D, Zhao P, Zhong F, Korlach J, Turner S (2009) Realtime DNA sequencing from single polymerase molecules. Science 323(5910):133-138

Galvao VC, Nordstrom KJ, Lanz C, Sulz P, Mathieu J, Pose D, Schmid M, Weigel D, Schneeberger K (2012) Synteny-based mapping-by-sequencing enabled by targeted enrichment. Plant J 71(3):517-526

Goff SA, Ricke D, Lan TH, Presting G, Wang R, Dunn M, Glazebrook J, Sessions A, Oeller P, Varma H, Hadley D, Hutchison D, Martin C, Katagiri F, Lange BM, Moughamer T, Xia Y, Budworth P, Zhong J, Miguel T, Paszkowski U, Zhang S, Colbert M, Sun WL, Chen L, Cooper B, Park S, Wood TC, Mao L, Quail P, Wing R, Dean R, Yu Y, Zharkikh A, Shen R, Sahasrabudhe S, Thomas A, Cannings R, Gutin A, Pruss D, Reid J, Tavtigian S, Mitchell J, Eldredge G, Scholl T, Miller RM, Bhatnagar S, Adey N, Rubano T, Tusneem N, Robinson R, Feldhaus J, Macalma T, Oliphant A, Briggs S (2002) A draft sequence of the rice genome (Oryza sativa L. ssp. japonica). Science 296(5565):92-100

Guo X, Zhang Z, Gerstein MB, Zheng D (2009) Small RNAs originated from pseudogenes: cis- or trans-acting? PLoS Comput Biol 5:e1000449

Guo S, Zhang J, Sun H, Salse J, Lucas WJ, Zhang H, Zheng Y, Mao L, Ren Y, Wang Z, Min J, Guo X, Murat F, Ham BK, Zhang Z, Gao S, Huang M, Xu Y, Zhong S, Bombarely A, Mueller LA, Zhao H, He H, Zhang Y, Zhang Z, Huang S, Tan T, Pang E, Lin K, Hu Q, Kuang H, Ni P, Wang B, Liu J, Kou Q, Hou W, Zou X, Jiang J, Gong G, Klee K, Schoof H, Huang Y, Hu X, Dong S, Liang D, Wang J, Wu K, Xia Y, Zhao X, Zheng Z, Xing M, Liang X, Huang B, Lv T, Wang J, Yin Y, Yi H, Li R, Wu M, Levi A, Zhang X, Giovannoni JJ, Wang J, Li Y, Fei Z, Xu Y (2012a) The draft genome of watermelon (Citrullus lanatus) and resequencing of 20 diverse accessions. Nat Genet 45(1):51-58

Guo Z, Tucker DM, Lu J, Kishore V, Gay G (2012b) Evaluation of genome-wide selection efficiency in maize nested association mapping populations. Theor Appl Genet 124(2):261-275

Harper AL, Trick M, Higgins J, Fraser F, Clissold L, Wells R, Hattori C, Werner P, Bancroft I (2012) Associative transcriptomics of traits in the polyploid crop species Brassica napus. Nat Biotechnol 30(8):798-802

Heffner EL, Sorrells ME, Jannink JL (2009) Genomic Selection for crop improvement. Crop Sci 49(1):1-12 
Henry RJ, Edwards M, Waters DL, Gopala Krishnan S, Bundock P, Sexton TR, Masouleh AK, Nock CJ, Pattemore J (2012) Application of large-scale sequencing to marker discovery in plants. $\mathrm{J}$ Biosci 37(5):829-841

Higgins JA, Magusin A, Trick M, Fraser F, Bancroft I (2012) Use of mRNA-Seq to discriminate contributions to the transcriptome from the constituent genomes of the polyploid crop species Brassica napus. BMC Genomics 13(1):247

Honsdorf N, Becker HC, Ecke W (2010) Association mapping for phenological, morphological, and quality traits in canola quality winter rapeseed (Brassica napus L.). Genome 53(11):899-907

Hu Z, Hua W, Huang S, Yang H, Zhan G, Wang X, Liu G, Wang H (2012a) Discovery of pod shatter-resistant associated SNPs by deep sequencing of a representative library followed by bulk segregant analysis in rapeseed. PLoS ONE 7(4):e34253

Hu ZY, Huang SM, Sun MY, Wang HZ, Hua W (2012b) Development and application of single nucleotide polymorphism markers in the polyploid Brassica napus by 454 sequencing of expressed sequence tags. Plant Breed 131(2):293-299

Huang S, Li R, Zhang Z, Li L, Gu X, Fan W, Lucas WJ, Wang X, Xie B, Ni P, Ren Y, Zhu H, Li J, Lin K, Jin W, Fei Z, Li G, Staub J, Kilian A, van der Vossen EA, Wu Y, Guo J, He J, Jia Z, Ren Y, Tian G, Lu Y, Ruan J, Qian W, Wang M, Huang Q, Li B, Xuan Z, Cao J, Asan WuZ, Zhang J, Cai Q, Bai Y, Zhao B, Han Y, Li Y, Li X, Wang S, Shi Q, Liu S, Cho WK, Kim JY, Xu Y, Heller-Uszynska K, Miao H, Cheng Z, Zhang S, Wu J, Yang Y, Kang H, Li M, Liang H, Ren X, Shi Z, Wen M, Jian M, Yang H, Zhang G, Yang Z, Chen R, Liu S, Li J, Ma L, Liu H, Zhou Y, Zhao J, Fang X, Li G, Fang L, Li Y, Liu D, Zheng H, Zhang Y, Qin N, Li Z, Yang G, Yang S, Bolund L, Kristiansen K, Zheng H, Li S, Zhang X, Yang H, Wang J, Sun R, Zhang B, Jiang S, Wang J, Du Y, Li S (2009) The genome of the cucumber, Cucumis sativus L. Nat Genet 41(12):1275-1281

International Human Genome Consortium (2004) Finishing the euchromatic sequence of the human genome. Nature 431(7011):931-945

International Peach Genome Initiative (2010). http://www.rosaceae. org/peach/genome

Kaul S, Koo HL, Jenkins J, Rizzo M, Rooney T, Tallon LJ, Feldblyum T, Nierman W, Benito MI, Lin XY, Town CD, Venter JC, Fraser CM, Tabata S, Nakamura Y, Kaneko T, Sato S, Asamizu E, Kato T, Kotani H, Sasamoto S, Ecker JR, Theologis A, Federspiel NA, Palm CJ, Osborne BI, Shinn P, Conway AB, Vysotskaia VS, Dewar K, Conn L, Lenz CA, Kim CJ, Hansen NF, Liu SX, Buehler E, Altafi H, Sakano H, Dunn P, Lam B, Pham PK, Chao Q, Nguyen M, Yu GX, Chen HM, Southwick A, Lee JM, Miranda M, Toriumi MJ, Davis RW, Wambutt R, Murphy G, Dusterhoft A, Stiekema W, Pohl T, Entian KD, Terryn N, Volckaert G, Salanoubat M, Choisne N, Rieger M, Ansorge W, Unseld M, Fartmann B, Valle G, Artiguenave F, Weissenbach J, Quetier F, Wilson RK, de la Bastide M, Sekhon M, Huang E, Spiegel L, Gnoj L, Pepin K, Murray J, Johnson D, Habermann K, Dedhia N, Parnell L, Preston R, Hillier L, Chen E, Marra M, Martienssen R, McCombie WR, Mayer K, White O, Bevan M, Lemcke K, Creasy TH, Bielke C, Haas B, Haase D, Maiti R, Rudd S, Peterson J, Schoof H, Frishman D, Morgenstern B, Zaccaria P, Ermolaeva M, Pertea M, Quackenbush J, Volfovsky N, Wu DY, Lowe TM, Salzberg SL, Mewes HW, Rounsley S, Bush D, Subramaniam S, Levin I, Norris S, Schmidt R, Acarkan A, Bancroft I, Quetier F, Brennicke A, Eisen JA, Bureau T, Legault BA, Le QH, Agrawal N, Yu Z, Martienssen R, Copenhaver GP, Luo S, Pikaard CS, Preuss D, Paulsen IT, Sussman M, Britt AB, Selinger DA, Pandey R, Mount DW, Chandler VL, Jorgensen RA, Pikaard C, Juergens G, Meyerowitz EM, Theologis A, Dangl J, Jones JDG, Chen M, Chory J, Somerville MC, In AG (2000) Analysis of the genome sequence of the flowering plant Arabidopsis thaliana. Nature 408:796-815
Klein HU, Bartenhagen C, Kohlmann A, Grossmann V, Ruckert C, Haferlach T, Dugas M (2011) R453Plus1Toolbox: an R/Bioconductor package for analyzing Roche 454 Sequencing data. Bioinformatics 27(8):1162-1163

Koo DH, Hong CP, Batley J, Chung YS, Edwards D, Bang JW, Hur Y, Lim YP (2011) Rapid divergence of repetitive DNAs in Brassica relatives. Genomics 97(3):173-185

Korbes AP, Machado RD, Guzman F, Almerao MP, de Oliveira LF, Loss-Morais G, Turchetto-Zolet AC, Cagliari A, Dos SantosMaraschin F, Margis-Pinheiro M, Margis R (2012) Identifying conserved and novel microRNAs in developing seeds of Brassica napus using deep sequencing. PLoS ONE 7(11):e50663

Laitinen RA, Schneeberger K, Jelly NS, Ossowski S, Weigel D (2010) Identification of a spontaneous frame shift mutation in a nonreference Arabidopsis accession using whole genome sequencing. Plant Physiol 153(2):652-654

Lam HM, Xu X, Liu X, Chen W, Yang G, Wong FL, Li MW, He W, Qin N, Wang B, Li J, Jian M, Wang J, Shao G, Wang J, Sun SS, Zhang G (2010) Resequencing of 31 wild and cultivated soybean genomes identifies patterns of genetic diversity and selection. Nat Genet 42(12):1053-1059

Li F, Kitashiba H, Inaba K, Nishio T (2009) A Brassica rapa linkage map of EST-based SNP markers for identification of candidate genes controlling flowering time and leaf morphological traits. DNA Res 16(6):311-323

Li R, Fan W, Tian G, Zhu H, He L, Cai J, Huang Q, Cai Q, Li B, Bai Y, Zhang Z, Zhang Y, Wang W, Li J, Wei F, Li H, Jian M, Li J, Zhang Z, Nielsen R, Li D, Gu W, Yang Z, Xuan Z, Ryder OA, Leung FC, Zhou Y, Cao J, Sun X, Fu Y, Fang X, Guo X, Wang B, Hou R, Shen F, Mu B, Ni P, Lin R, Qian W, Wang G, Yu C, Nie W, Wang J, Wu Z, Liang H, Min J, Wu Q, Cheng S, Ruan J, Wang M, Shi Z, Wen M, Liu B, Ren X, Zheng H, Dong D, Cook K, Shan G, Zhang H, Kosiol C, Xie X, Lu Z, Zheng H, Li Y, Steiner CC, Lam TT, Lin S, Zhang Q, Li G, Tian J, Gong T, Liu H, Zhang D, Fang L, Ye C, Zhang J, Hu W, Xu A, Ren Y, Zhang G, Bruford MW, Li Q, Ma L, Guo Y, An N, Hu Y, Zheng Y, Shi Y, Li Z, Liu Q, Chen Y, Zhao J, Qu N, Zhao S, Tian F, Wang X, Wang H, Xu L, Liu X, Vinar T, Wang Y, Lam TW, Yiu SM, Liu S, Zhang H, Li D, Huang Y, Wang X, Yang G, Jiang Z, Wang J, Qin N, Li L, Li J, Bolund L, Kristiansen K, Wong GK, Olson M, Zhang X, Li S, Yang H, Wang J, Wang J (2010) The sequence and de novo assembly of the giant panda genome. Nature 463(7279):311-317

Lister R, O'Malley RC, Tonti-Filippini J, Gregory BD, Berry CC, Millar AH, Ecker JR (2008) Highly integrated singlebase resolution maps of the epigenome in Arabidopsis. Cell 133(3):523-536

Lister R, Pelizzola M, Dowen RH, Hawkins RD, Hon G, TontiFilippini J, Nery JR, Lee L, Ye Z, Ngo QM, Edsall L, Antosiewicz-Bourget J, Stewart R, Ruotti V, Millar AH, Thomson JA, Ren B, Ecker JR (2009) Human DNA methylomes at base resolution show widespread epigenomic differences. Nature 462(7271):315-322

Lorenc M, Boskovic Z, Stiller J, Duran C, Edwards D (2012) Role of bioinformatics as a tool for oilseed Brassica species. Genetics, genomics and breeding of oilseed Brassicas. Science Publishers Inc, New Hampshire, pp 194-205

Love CG, Graham NS, Lochlainn SO, Bowen HC, May ST, White PJ, Broadley MR, Hammond JP, King GJ (2010) A Brassica exon array for whole-transcript gene expression profiling. PLoS ONE 5:e12812

Mammadov J, Aggarwal R, Buyyarapu R, Kumpatla S (2012) SNP markers and their impact on plant breeding. Int J Plant Genomics 2012:728398

Mayer KF, Waugh R, Brown JW, Schulman A, Langridge P, Platzer M, Fincher GB, Muehlbauer GJ, Sato K, Close TJ, Wise RP, 
Stein N (2012) A physical, genetic and functional sequence assembly of the barley genome. Nature 491(7426):711-716

McCouch SR, Zhao KY, Wright M, Tung CW, Ebana K, Thomson M, Reynolds A, Wang D, DeClerck G, Ali ML, McClung A, Eizenga G, Bustamante C (2010) Development of genome-wide SNP assays for rice. Breed Sci 60(5):524-535

Ming R, Hou S, Feng Y, Yu Q, Dionne-Laporte A, Saw JH, Senin P, Wang W, Ly BV, Lewis KL, Salzberg SL, Feng L, Jones MR, Skelton RL, Murray JE, Chen C, Qian W, Shen J, Du P, Eustice M, Tong E, Tang H, Lyons E, Paull RE, Michael TP, Wall K, Rice DW, Albert H, Wang ML, Zhu YJ, Schatz M, Nagarajan N, Acob RA, Guan P, Blas A, Wai CM, Ackerman CM, Ren Y, Liu C, Wang J, Wang J, Na JK, Shakirov EV, Haas B, Thimmapuram J, Nelson D, Wang X, Bowers JE, Gschwend AR, Delcher AL, Singh R, Suzuki JY, Tripathi S, Neupane K, Wei H, Irikura B, Paidi M, Jiang N, Zhang W, Presting G, Windsor A, Navajas-Perez R, Torres MJ, Feltus FA, Porter B, Li Y, Burroughs AM, Luo MC, Liu L, Christopher DA, Mount SM, Moore PH, Sugimura T, Jiang J, Schuler MA, Friedman V, Mitchell-Olds T, Shippen DE, dePamphilis CW, Palmer JD, Freeling M, Paterson AH, Gonsalves D, Wang L, Alam M (2008) The draft genome of the transgenic tropical fruit tree papaya (Carica papaya Linnaeus). Nature 452:991-6

Minoche AE, Dohm JC, Himmelbauer H (2011) Evaluation of genomic high-throughput sequencing data generated on Illumina HiSeq and genome analyzer systems. Genome Biol 12(11):R112

Morey M, Fernandez-Marmiesse A, Castineiras D, Fraga JM, Couce ML, Cocho JA (2013) A glimpse into past, present, and future DNA sequencing. Mol Genet Metab 110:3-24

Mun JH, Kwon SJ, Yang TJ, Kim HS, Choi BS, Baek S, Kim JS, Jin M, Kim JA, Lim MH, Lee SI, Kim HI, Kim H, Lim YP, Park BS (2008) The first generation of a BAC-based physical map of Brassica rapa. BMC Genomics 9:280

Mun JH, Kwon SJ, Yang TJ, Seol YJ, Jin M, Kim JA, Lim MH, Kim JS, Baek S, Choi BS, Yu HJ, Kim DS, Kim N, Lim KB, Lee SI, Hahn JH, Lim YP, Bancroft I, Park BS (2009) Genome-wide comparative analysis of the Brassica rapa gene space reveals genome shrinkage and differential loss of duplicated genes after whole genome triplication. Genome Biol 10(10):R111

Mun JH, Kwon SJ, Seol YJ, Kim JA, Jin M, Kim JS, Lim MH, Lee SI, Hong JK, Park TH, Lee SC, Kim BJ, Seo MS, Baek S, Lee MJ, Shin JY, Hahn JH, Hwang YJ, Lim KB, Park JY, Lee J, Yang TJ, Yu HJ, Choi IY, Choi BS, Choi SR, Ramchiary N, Lim YP, Fraser F, Drou N, Soumpourou E, Trick M, Bancroft I, Sharpe AG, Parkin IA, Batley J, Edwards D, Park BS (2010) Sequence and structure of Brassica rapa chromosome A3. Genome Biol 11(9):R94

Mundry M, Bornberg-Bauer E, Sammeth M, Feulner PG (2012) Evaluating characteristics of de novo assembly software on 454 transcriptome data: a simulation approach. PLoS ONE 7(2):e31410

Myrick KV, Gelbart WM (2007) A modified universal fast walking method for single-tube transposon mapping. Nat Protoc 2:1556-1563

Obermeier C, Hosseini B, Friedt W, Snowdon R (2009) Gene expression profiling via LongSAGE in a non-model plant species: a case study in seeds of Brassica napus. BMC Genomics 10:295

Ozsolak F, Milos PM (2011) Single-molecule direct RNA sequencing without cDNA synthesis. Wiley Interdiscip Rev RNA 2(4):565-570

Parkin IA, Clarke WE, Sidebottom C, Zhang W, Robinson SJ, Links MG, Karcz S, Higgins EE, Fobert P, Sharpe AG (2010) Towards unambiguous transcript mapping in the allotetraploid Brassica napus. Genome 53(11):929-938

Paterson AH, Bowers JE, Bruggmann R, Dubchak I, Grimwood J, Gundlach H, Haberer G, Hellsten U, Mitros T, Poliakov A,
Schmutz J, Spannagl M, Tang H, Wang X, Wicker T, Bharti AK, Chapman J, Feltus FA, Gowik U, Grigoriev IV, Lyons E, Maher CA, Martis M, Narechania A, Otillar RP, Penning BW, Salamov AA, Wang Y, Zhang L, Carpita NC, Freeling M, Gingle AR, Hash CT, Keller B, Klein P, Kresovich S, McCann MC, Ming R, Peterson DG, Mehboob ur R, Ware D, Westhoff P, Mayer KF, Messing J, Rokhsar DS (2009) The Sorghum bicolor genome and the diversification of grasses. Nature 457(7229):551-556

Picho J-PD, Rivière N, Duarte J, Dugas O, Wilmer JA, Gerhardt DJ, Richmond T, Albert TJ, Jeddeloh JA (2010) Rapeseed (B. napus) SNP discovery using a dedicated sequence capture protocol and 454 sequencing. In: Plant and Animal Genomes XVIII Conference, San Diego

Poland JA, Bradbury PJ, Buckler ES, Nelson RJ (2011) Genomewide nested association mapping of quantitative resistance to northern leaf blight in maize. Proc Natl Acad Sci USA 108(17):6893-6898

Pushkarev D, Neff NF, Quake SR (2009) Single-molecule sequencing of an individual human genome. Nat Biotechnol 27(9):847-850

Sanger F, Nicklen S, Coulson AR (1977) DNA sequencing with chain-terminating inhibitors. Proc Natl Acad Sci USA 74(12):5463-5467

Schmutz J, Cannon SB, Schlueter J, Ma J, Mitros T, Nelson W, Hyten DL, Song Q, Thelen JJ, Cheng J, Xu D, Hellsten U, May GD, Yu Y, Sakurai T, Umezawa T, Bhattacharyya MK, Sandhu D, Valliyodan B, Lindquist E, Peto M, Grant D, Shu S, Goodstein D, Barry K, Futrell-Griggs M, Abernathy B, Du J, Tian Z, Zhu L, Gill N, Joshi T, Libault M, Sethuraman A, Zhang XC, Shinozaki K, Nguyen HT, Wing RA, Cregan P, Specht J, Grimwood J, Rokhsar D, Stacey G, Shoemaker RC, Jackson SA (2010) Genome sequence of the palaeopolyploid soybean. Nature 463(7278):178-183

Sidebottom CH, koh CS, Gilchrist E, George H, Sharpe A (2012) Mutation detection in Brassica napus using Illumina sequencing. In: International plant and animal genome conference, San Diego, CA

Snowdon RJ, Luy FLI (2012) Potential to improve oilseed rape and canola breeding in the genomics era. Plant Breed 131(3):351-360

Srivastava S, Srivastava AK, Suprasanna P, D’Souza SF (2012) Identification and profiling of arsenic stress-induced microRNAs in Brassica juncea. J Exp Bot 64(1):303-315

Stower H (2012) Plant genomics: associative transcriptomics. Nat Rev Genet 13:597

Strickler SR, Bombarely A, Mueller LA (2012) Designing a transcriptome next-generation sequencing project for a nonmodel plant species1. Am J Bot 99(2):257-266

Subbaiyan GK, Waters DL, Katiyar SK, Sadananda AR, Vaddadi S, Henry RJ (2012) Genome-wide DNA polymorphisms in elite indica rice inbreds discovered by whole-genome sequencing. Plant Biotechnol J 10(6):623-634

Sun Q, Zhou G, Cai Y, Fan Y, Zhu X, Liu Y, He X, Shen J, Jiang H, Hu D, Pan Z, Xiang L, He G, Dong D, Yang J (2012) Transcriptome analysis of stem development in the tumourous stem mustard Brassica juncea var. tumida Tsen et Lee by RNA sequencing. BMC Plant Biol 12:53

Syed NH, Kalyna M, Marquez Y, Barta A, Brown JW (2012) Alternative splicing in plants-coming of age. Trends Plant Sci 17(10):616-623

The International Brachypodium Initiative (2010) Genome sequencing and analysis of the model grass Brachypodium distachyon. Nature 463(7282):763-768

Tollenaere R, Hayward A, Dalton-Morgan J, Campbell E, Lee JR, Lorenc MT, Manoli S, Stiller J, Raman R, Raman H, Edwards D, Batley J (2012) Identification and characterization of candidate Rlm4 blackleg resistance genes in Brassica napus using next-generation sequencing. Plant Biotechnol J 10:709-715 
Town CD, Cheung F, Maiti R, Crabtree J, Haas BJ, Wortman JR, Hine EE, Althoff R, Arbogast TS, Tallon LJ, Vigouroux M, Trick M, Bancroft I (2006) Comparative genomics of Brassica oleracea and Arabidopsis thaliana reveal gene loss, fragmentation, and dispersal after polyploidy. Plant Cell 18(6):1348-1359

Trick M, Cheung F, Drou N, Fraser F, Lobenhofer EK, Hurban P, Magusin A, Town CD, Bancroft I (2009a) A newly-developed community microarray resource for transcriptome profiling in Brassica species enables the confirmation of Brassica-specific expressed sequences. BMC Plant Biol 9:50. doi10.1186/1471-2229-9-50

Trick M, Long Y, Meng J, Bancroft I (2009b) Single nucleotide polymorphism (SNP) discovery in the polyploid Brassica napus using Solexa transcriptome sequencing. Plant Biotechnol J 7(4):334-346

Troncoso-Ponce MA, Kilaru A, Cao X, Durrett TP, Fan J, Jensen JK, Thrower NA, Pauly M, Wilkerson C, Ohlrogge JB (2011) Comparative deep transcriptional profiling of four developing oilseeds. Plant J 68(6):1014-1027

Tuskan GA, Difazio S, Jansson S, Bohlmann J, Grigoriev I, Hellsten U, Putnam N, Ralph S, Rombauts S, Salamov A, Schein J, Sterck L, Aerts A, Bhalerao RR, Bhalerao RP, Blaudez D, Boerjan W, Brun A, Brunner A, Busov V, Campbell M, Carlson J, Chalot M, Chapman J, Chen GL, Cooper D, Coutinho PM, Couturier J, Covert S, Cronk Q, Cunningham R, Davis J, Degroeve S, Dejardin A, Depamphilis C, Detter J, Dirks B, Dubchak I, Duplessis S, Ehlting J, Ellis B, Gendler K, Goodstein D, Gribskov M, Grimwood J, Groover A, Gunter L, Hamberger B, Heinze B, Helariutta Y, Henrissat B, Holligan D, Holt R, Huang W, Islam-Faridi N, Jones S, Jones-Rhoades M, Jorgensen R, Joshi C, Kangasjarvi J, Karlsson J, Kelleher C, Kirkpatrick R, Kirst M, Kohler A, Kalluri U, Larimer F, Leebens-Mack J, Leple JC, Locascio P, Lou Y, Lucas S, Martin F, Montanini B, Napoli C, Nelson DR, Nelson C, Nieminen K, Nilsson O, Pereda V, Peter G, Philippe R, Pilate G, Poliakov A, Razumovskaya J, Richardson P, Rinaldi C, Ritland K, Rouze P, Ryaboy D, Schmutz J, Schrader J, Segerman B, Shin H, Siddiqui A, Sterky F, Terry A, Tsai CJ, Uberbacher E, Unneberg P, Vahala J, Wall K, Wessler S, Yang G, Yin T, Douglas C, Marra M, Sandberg G, Van de Peer Y, Rokhsar D (2006) The genome of black cottonwood, Populus trichocarpa (Torr. \& Gray). Science 313(5793): 1596-1604

U N (1935) Genome analysis in Brassica with special reference to the experimental formation of B. napus and peculiar mode of fertilization. Jpn J Bot 7:389-452

Varshney RK, Nayak SN, May GD, Jackson SA (2009) Next-generation sequencing technologies and their implications for crop genetics and breeding. Trends Biotechnol 27(9):522-530

Wang Z, Fang B, Chen J, Zhang X, Luo Z, Huang L, Chen X, Li Y (2010) De novo assembly and characterization of root transcriptome using Illumina paired-end sequencing and development of cSSR markers in sweet potato (Ipomoea batatas). BMC Genomics 11:726

Wang L, Yu X, Wang H, Lu YZ, de Ruiter M, Prins M, He YK (2011a) A novel class of heat-responsive small RNAs derived from the chloroplast genome of Chinese cabbage (Brassica rapa). BMC Genomics 12:289

Wang X, Wang H, Wang J, Sun R, Wu J, Liu S, Bai Y, Mun JH, Bancroft I, Cheng F, Huang S, Li X, Hua W, Wang J, Wang X, Freeling M, Pires JC, Paterson AH, Chalhoub B, Wang B, Hayward A, Sharpe AG, Park BS, Weisshaar B, Liu B, Li B, Liu B, Tong C, Song C, Duran C, Peng C, Geng C, Koh C, Lin C, Edwards D, Mu D, Shen D, Soumpourou E, Li F, Fraser F, Conant G, Lassalle G, King GJ, Bonnema G, Tang H, Wang $\mathrm{H}$, Belcram H, Zhou H, Hirakawa H, Abe H, Guo H, Wang H, Jin H, Parkin IA, Batley J, Kim JS, Just J, Li J, Xu J, Deng J,
Kim JA, Li J, Yu J, Meng J, Wang J, Min J, Poulain J, Wang J, Hatakeyama K, Wu K, Wang L, Fang L, Trick M, Links MG, Zhao M, Jin M, Ramchiary N, Drou N, Berkman PJ, Cai Q, Huang Q, Li R, Tabata S, Cheng S, Zhang S, Zhang S, Huang S, Sato S, Sun S, Kwon SJ, Choi SR, Lee TH, Fan W, Zhao X, Tan X, Xu X, Wang Y, Qiu Y, Yin Y, Li Y, Du Y, Liao Y, Lim Y, Narusaka Y, Wang Y, Wang Z, Li Z, Wang Z, Xiong Z, Zhang Z (2011b) The genome of the mesopolyploid crop species Brassica rapa. Nat Genet 43(10):1035-1039

Wang F, Li L, Liu L, Li H, Zhang Y, Yao Y, Ni Z, Gao J (2012a) Highthroughput sequencing discovery of conserved and novel microRNAs in Chinese cabbage (Brassica rapa L. ssp. pekinensis). Mol Genet Genomics 287(7):555-563

Wang K, Wang Z, Li F, Ye W, Wang J, Song G, Yue Z, Cong L, Shang $\mathrm{H}$, Zhu S, Zou C, Li Q, Yuan Y, Lu C, Wei H, Gou C, Zheng Z, Yin Y, Zhang X, Liu K, Wang B, Song C, Shi N, Kohel RJ, Percy RG, Yu JZ, Zhu YX, Wang J, Yu S (2012b) The draft genome of a diploid cotton Gossypium raimondii. Nat Genet 44(10):1098-1103

Wei LJ, Xiao ML, An ZS, Ma B, Mason AS, Qian W, Li JN, Fu DH (2013) New insights into nested long terminal repeat retrotransposons in Brassica species. Mol Plant 6:470-482

Westermeier P, Wenzel G, Mohler V (2009) Development and evaluation of single-nucleotide polymorphism markers in allotetraploid rapeseed (Brassica napus L.). Theor Appl Genet 119:1301-1311

Xia Q, Guo Y, Zhang Z, Li D, Xuan Z, Li Z, Dai F, Li Y, Cheng D, Li R, Cheng T, Jiang T, Becquet C, Xu X, Liu C, Zha X, Fan W, Lin Y, Shen Y, Jiang L, Jensen J, Hellmann I, Tang S, Zhao P, Xu H, Yu C, Zhang G, Li J, Cao J, Liu S, He N, Zhou Y, Liu H, Zhao J, Ye C, Du Z, Pan G, Zhao A, Shao H, Zeng W, Wu P, Li C, Pan M, Li J, Yin X, Li D, Wang J, Zheng H, Wang W, Zhang X, Li S, Yang H, Lu C, Nielsen R, Zhou Z, Wang J, Xiang Z, Wang J (2009) Complete resequencing of 40 genomes reveals domestication events and genes in silkworm (Bombyx). Science 326(5951):433-436

Xu J, Qian X, Wang X, Li R, Cheng X, Yang Y, Fu J, Zhang S, King GJ, Wu J, Liu K (2010) Construction of an integrated genetic linkage map for the A genome of Brassica napus using SSR markers derived from sequenced BACs in B. rapa. BMC Genomics 11:594

Xu X, Pan S, Cheng S, Zhang B, Mu D, Ni P, Zhang G, Yang S, Li R, Wang J, Orjeda G, Guzman F, Torres M, Lozano R, Ponce O, Martinez D, De la Cruz G, Chakrabarti SK, Patil VU, Skryabin KG, Kuznetsov BB, Ravin NV, Kolganova TV, Beletsky AV, Mardanov AV, Di Genova A, Bolser DM, Martin DM, Li G, Yang Y, Kuang H, Hu Q, Xiong X, Bishop GJ, Sagredo B, Mejia N, Zagorski W, Gromadka R, Gawor J, Szczesny P, Huang S, Zhang Z, Liang C, He J, Li Y, He Y, Xu J, Zhang Y, Xie B, Du Y, Qu D, Bonierbale M, Ghislain M, Herrera Mdel R, Giuliano G, Pietrella M, Perrotta G, Facella P, O'Brien K, Feingold SE, Barreiro LE, Massa GA, Diambra L, Whitty BR, Vaillancourt B, Lin H, Massa AN, Geoffroy M, Lundback S, DellaPenna D, Buell CR, Sharma SK, Marshall DF, Waugh R, Bryan GJ, Destefanis M, Nagy I, Milbourne D, Thomson SJ, Fiers M, Jacobs JM, Nielsen KL, Sonderkaer M, Iovene M, Torres GA, Jiang J, Veilleux RE, Bachem CW, de Boer J, Borm T, Kloosterman B, van Eck H, Datema E, Hekkert BL, Goverse A, van Ham RC, Visser RG (2011) Genome sequence and analysis of the tuber crop potato. Nature 475(7355):189-195

Xu M, Dong Y, Zhang Q, Zhang A, Luo Y, Sun J, Fan Y, Wang L (2012a) Identification of miRNAs and their targets from Brassica napus by high-throughput sequencing and degradome analysis. BMC Genomics 13:42

Xu Q, Chen LL, Ruan X, Chen D, Zhu A, Chen C, Bertrand D, Jiao WB, Hao BH, Lyon MP, Chen J, Gao S, Xing F, Lan H, Chang 
JW, Ge X, Lei Y, Hu Q, Miao Y, Wang L, Xiao S, Biswas MK, Zeng W, Guo F, Cao H, Yang X, Xu XW, Cheng YJ, Xu J, Liu JH, Luo OJ, Tang Z, Guo WW, Kuang H, Zhang HY, Roose ML, Nagarajan N, Deng XX, Ruan Y (2012b) The draft genome of sweet orange (Citrus sinensis). Nat Genet 45:59-66

Yu J, Hu S, Wang J, Wong GK, Li S, Liu B, Deng Y, Dai L, Zhou Y, Zhang X, Cao M, Liu J, Sun J, Tang J, Chen Y, Huang X, Lin W, Ye C, Tong W, Cong L, Geng J, Han Y, Li L, Li W, Hu G, Huang X, Li W, Li J, Liu Z, Li L, Liu J, Qi Q, Liu J, Li L, Li T, Wang X, Lu H, Wu T, Zhu M, Ni P, Han H, Dong W, Ren X, Feng X, Cui P, Li X, Wang H, Xu X, Zhai W, Xu Z, Zhang J, He S, Zhang J, Xu J, Zhang K, Zheng X, Dong J, Zeng W, Tao L, Ye J, Tan J, Ren X, Chen X, He J, Liu D, Tian W, Tian C, Xia H, Bao Q, Li G, Gao H, Cao T, Wang J, Zhao W, Li P, Chen W, Wang X, Zhang Y, Hu J, Wang J, Liu S, Yang J, Zhang G, Xiong Y, Li Z, Mao L, Zhou C, Zhu Z, Chen R, Hao B, Zheng W, Chen S, Guo W, Li G, Liu S, Tao M, Wang J, Zhu L, Yuan L, Yang H (2002) A draft sequence of the rice genome (Oryza sativa L. ssp. indica). Science 296(5565):79-92

Yu SC, Zhang FL, Yu YJ, Zhang DS, Zhao XY, Wang WH (2012a) Transcriptome profiling of dehydration stress in the Chinese cabbage (Brassica rapa L. ssp pekinensis) by tag sequencing. Plant Mol Biol Report 30(1):17-28

Yu X, Wang H, Lu Y, de Ruiter M, Cariaso M, Prins M, van Tunen A, $\mathrm{He} Y$ (2012b) Identification of conserved and novel microRNAs that are responsive to heat stress in Brassica rapa. J Exp Bot 63(2):1025-1038

Zhang G, Guo G, Hu X, Zhang Y, Li Q, Li R, Zhuang R, Lu Z, He Z, Fang X, Chen L, Tian W, Tao Y, Kristiansen K, Zhang X, Li
S, Yang H, Wang J, Wang J (2010) Deep RNA sequencing at single base-pair resolution reveals high complexity of the rice transcriptome. Genome Res 20(5):646-654

Zhao K, Aranzana MJ, Kim S, Lister C, Shindo C, Tang C, Toomajian C, Zheng H, Dean C, Marjoram P, Nordborg M (2007) An Arabidopsis example of association mapping in structured samples. PLoS Genet 3(1):e4

Zhao J, Artemyeva A, Del Carpio DP, Basnet RK, Zhang N, Gao J, Li F, Bucher J, Wang X, Visser RG, Bonnema G (2010) Design of a Brassica rapa core collection for association mapping studies. Genome 53(11):884-898

Zhao YT, Wang M, Fu SX, Yang WC, Qi CK, Wang XJ (2012) Small RNA profiling in two Brassica napus cultivars identifies microRNAs with oil production- and development-correlated expression and new small RNA classes. Plant Physiol 158(2):813-823

Zhou R, Moshgabadi N, Adams KL (2011a) Extensive changes to alternative splicing patterns following allopolyploidy in natural and resynthesized polyploids. Proc Natl Acad Sci USA 108(38):16122-16127

Zhou X, Fei Z, Thannhauser TW, Li L (2011b) Transcriptome analysis of ectopic chloroplast development in green curd cauliflower (Brassica oleracea L. var. botrytis). BMC Plant Biol 11:169

Zhou ZS, Song JB, Yang ZM (2012) Genome-wide identification of Brassica napus microRNAs and their targets in response to cadmium. J Exp Bot 63(12):4597-4613

Zou J, Jiang C, Cao Z, Li R, Long Y, Chen S, Meng J (2010) Association mapping of seed oil content in Brassica napus and comparison with quantitative trait loci identified from linkage mapping. Genome 53(11):908-916 